\title{
The Dialectic of the Nature-Society-System
}

\author{
Christian Fuchs
}

ICT\&S Center: Advanded Studies and Research in Information and Communication Technologies \& Society, Sigmund Haffner Gasse 18, 5020 Salzburg, Austria; christian.fuchs@sbg.ac.at

\begin{abstract}
There are four logical possibilities for conceiving the relationship of nature and society: the reduction of society to nature, the projection of nature into society, dualism, and a nature-society-dialectic. This differentiation results in four different approaches.

Nature is a self-organizing system that produces an evolutionary hierarchy of interconnected systems with specific qualities. Society is a product of nature where humans produce and reproduce structures that enable and constrain human practices in dynamic processes. Parts of nature are observed and appropriated by humans from within society, these parts are socially constructed and form a subsystem of society.

The self-organization cycle of nature and the self-organization cycle of the socio-sphere are mutually connected in a productive cycle of society where natural self-organization serves as the material foundation that enables and constrains social self-organization and human production processes transform natural structures and incorporate these very structures into society as means of production (technologies, raw materials). The economy is that part of the socio-sphere where the relationship between nature and the socio-sphere is established, the mediation is achieved by human labour processes. Nature enters the economic process as material input in the form of means of production (constant capital): machines, raw materials, auxiliary materials. Organized nature that is part of the production process in the form of technology increases the productivity of labour and hence reduces the costs of variable capital (total amount of wages) and increases the speed of the production of surplus value.

The production system of modern society is oriented on economic profit and productivity, ecological depletion and pollution are by-products of modernization. The Fordist production model that originated in the West and was copied by the Soviet Union is one of the major causes of the global ecological crisis. The productive forces are in modern society
\end{abstract}

socially and ecologically destructive forces. In late capitalism there is a tendency of commodification and privatization of nature and human knowledge.

Especially in the later writings of Marx and Engels one can find formulations that suggest a productivist logic that sees nature as an enemy opposed to man, as a resource and object that must be mastered, exploited, and controlled. But throughout the works of Marx and Engels one can find many passages where they argue that there is an antagonism between capitalism and nature that results in ecological degradation and that a free society is also based on alternative, sustainable relationships between man and nature. The idea of an alternative societynature-relationship and of nature conservation can already be found in the works of Marx and Engels, they are precursors of ecological thinking.

In Orthodox Marxism dialectical thinking has been interpreted as deterministic and mechanic laws and misused for arguing that the Soviet system is a free society. An alternative is a dialectic that stresses human practice and that structures condition alternative possibilities for action. Dialectic thinkers like Herbert Marcuse and Ernst Bloch have argued that nature is a producing subject, a non-teleological subject (Marcuse). Describing nature as a subject implies that if man destroys nature the latter as a producing subject will probably produce uncontrollable negative effects on society and that hence nature should be appropriated in sustainable ways. Matter is a natural subject that acts upon itself, whereas man is a human selfconscious subject that acts upon nature and society.

Keywords: nature, society, social theory 


\section{Introduction}

The aim of this paper is to discuss the relationship of nature and society. Questions to which possible answers should be given are:

How are nature and society related?

How are ecological problems connected to the functional logic of modern society?

Which role does ecological thinking play in Marxist thinking?

The approach chosen for treating these questions is both influenced by systems theory and Marxist thinking. The systems approach allows describing society as dynamic, networked, and complex that is needed for analyzing the functioning and essence of the information society. Dialectical and Marxist thinking are related to this type of thinking because they consider reality as inherently changing and becoming. Connecting both types of approaches allows to take a critical look at information society dynamics and to connect the latter to the functional logic of modern society. The method employed in this paper advances from the abstract to the concrete, it first discusses the relationship of nature and society in general, then connects this issue to the one of modern society, and finally introduces aspects of sustainability and the information society.

Part II of this paper focuses on the relationship of nature and society. For doing so it first discusses the difference between humans and animals (II.1), introduces a typology for classifying approaches on the relationship of nature and society (II.2), then advances to the more concrete topic of nature in modern society (II.3), discusses the role of nature in Marxism (II.4), and points out some foundations of a specific form of Ecological Marxism (II.5).

\section{Some Remarks on the Relationship of Nature and Society}

\section{1. The Disembedding of the Human Being from the Animal World}

The behaviour of animals is largely based on instinct, although learning exists to a certain, limited extent. The range and complexity of learned behaviour in human beings is by far greater than in any animal. Chimpanzees have a considerable learning capacity in comparison to other animals, but as experiments show they completely lack a comparison to human learning capabilities. In contrast to all animals, the behaviour of humans is not genetically programmed and led by instincts. Humans rely much more on learned and socialised patterns of behaviour. The plurality of human culture shows that the human genetic code does not contain specific instructions to behave in certain ways. You won't find this plurality concerning e.g. nests built by birds, dwellings built by apes, etc. Animals do not have selfconsciousness and they cannot make sense of the world. Hence one would not describe birds building a nest, working bees or chimpanzees playing together with terms such as "social", "societal", or "sociality". Such concepts are solely related to the human realm. Engels (1885: 504) has stressed that human history in difference to natural history is a development process of self-conscious organisms.

Constitutive for the qualitative difference of the way of organizing life has been that human beings e.g. for scavenging no longer simply used means (stick) for achieving immediately given ends (catching of a fruit on a tree), but that they also produce and preserve the means independent from immediate means, i.e. indirect precaution, production and preservation (Fuchs/Schlemm 2005, this reversal of ends and means has e.g. been discussed by Holzkamp 1985: 173, 193 who speaks of a "breakage of immediacy"). Such a reversal of ends and means has thus far only taken place once on planet earth, namely by the prehuman becoming human. Human beings begin to distinguish themselves from animals by starting to produce their means of subsistence by which they are indirectly producing their actual material life (Marx/Engels 1846: 21). Marx pointed out that man like animals lives from inorganic nature, he must remain in a continuing physical dialogue with nature in order to survive. Animals produce only their own immediate needs, "animals produce one-sidedly, whereas man produces universally; they produce only 
when immediate physical need compels them to do so, while man produces even when he is free from physical need and truly produces only in freedom from such need; they produce only themselves, while man reproduces the whole of nature; their products belong immediately to their physical bodies, while man freely confronts his own product. Animals produce only according to the standards and needs of the species to which they belong, while man is capable of producing according to the standards of every species and of applying to each object its inherent standard; hence, man also produces in accordance with the laws of beauty" (Marx 1844: 517). In the production of his life that includes the metabolism between society and nature and social reciprocity, man as the universal, objective species-being produces an objective world (gegenständliche Welt) and reproduces nature and his species according to his purposes. With the human being, history emerges: "the more that human beings become removed from animals in the narrower sense of the word, the more they make their own history consciously, the less becomes the influence of unforeseen effects and uncontrolled forces of this history, and the more accurately does the historical result correspond to the aim laid down in advance" (Engels 1886: 323). "The animal merely uses external nature, and brings about changes in it simply by his presence; man by his changes makes it serve his ends, masters it. This is the final, essential distinction between man and other animals, and once again it is labour that brings about this distinction" (Engels 1886: 452).

As Friedrich Engels (1886: 444-455) has shown in "The Part Played by Labour in the Transition from Ape to Man", the break-up of immediacy of behaviour (which is a foundation of the emergence of society) started with the erect posture in walking which resulted in the specialization of the hand which implies tools, tools enable production as human activities that transform nature. A differentiation of certain bodily forms can result in other organic differentiations. The specialization of the hand resulted in labour and the utilization of nature. The emergence of labour and production resulted in a co-evolution of society and consciousness. The genesis of man is due to a dialectic of labour and human capabilities (hand, language, increase of brain volume, consciousness etc.) which resulted in developments such as hunting, stock farming, agriculture, metal processing, navigation, pottery, art, science, legislation, politics etc. Idealistic conceptions of the development of man argue that consciousness existed prior to human social beings. Such ideas can e.g. be found in the traditional philosophy of consciousness. Other approaches point out that the development of consciousness can only be explained by assuming social interactions and social actions mediated by the usage of symbols. Both explanations are reductionistic, they assume either consciousness or society as determining the historical process. The emergence of the individual as a social being can only be explained adequately by a dialectical co-evolution of society (especially categories such as labour and production) and human abilities. Such a dialectical view argues that the emergence of culture is based on a dialectic of brain and body as well as of society and human abilities. This argumentation is still topical in modern anthropology (Geertz 1973: 48, Harris 1989: 39f). Man has "created himself" (Geertz 1973: 48).

As part of the production process man anticipates the future state of nature and society that he wants to attain and according to these ideas he shapes actual existence. "But what distinguishes the worst architect from the best of bees is this, that the architect raises his structure in imagination before he erects it in reality. At the end of every labour-process, we get a result that already existed in the imagination of the labourer at its commencement" (Marx 1867: 193). Such activity is based on creativity. Creativity is a basic skill of the human being. It means the ability to produce something new that seems desirable and helps to achieve defined goals. Man can create images of the future and actively strive to make these images become social reality. Other than animals man has ideals, visions, values, norms, dreams, hopes and expectations that are based on the ability of imagination that helps him to go beyond existing society and to create alternatives for future actions. Man is a cultural being, as typical expression of cultural activities he creates cultural manifestations such as art, literature, music, science, ideologies, world outlooks etc. 
The human being is a social, self-conscious, creative, producing, reflective, cultural, symbols- and language-using, active natural, labouring, objective, corporeal, living, real, sensuous, visionary, imaginative, designing, co-operative being that makes its own history and can strive towards freedom and autonomy (Fuchs 2003e). Other than animals it can produce in a self-conscious, active, imaginative, anticipatory, value-oriented manner. Animal behaviour is largely based on instincts, social behaviour on self-conscious, active, knowledgeable practices that allow choices and anticipation. In the animal world the meanings of signs are biologically determined and signs can't be recombined in order to form new meanings. In the human world the meanings of signs are socially determined and signs can be recombined in order to form more complex sign systems. Humans can invent new meanings and signs, animals are much more conservative and adaptive in their usage of signs, they hardly produce any new signs and do so only if they are compelled by nature to do so.

\section{II.2. A Typology of the Relationship of Nature and Society}

There are four logical possibilities for conceiving the relationship of nature and society: the reduction of society to nature, the projection of nature into society, dualism, and a nature-society-dialectic:

\section{2.1. Reductionism}

For reductionism nature and society are identical and nature determines society. Reducing society and culture to nature is dangerous as the fascist instrumentation of Social Darwinism for facilitating the annihilation of certain groups that are considered as biologically inferior has shown. Biologism/Naturalism doesn't acknowledge the distinction between nature and culture, it reduces culture to nature. National Socialism was based on a biologistic ideology that considered race, earth, folk, nature, homeland, family, and leadership as the essence of society. The barbarism of this ideology that is symbolically expressed by Auschwitz has shown how dangerous it is to reduce society to biology/nature.

\section{2.2. Projectionism (Anthropomorphism)}

Projectionism conceives nature and society as identical and society as the determining factor. Projecting society into nature results in anthropomorphism: natural systems are conceived in human and social terms. E.g. the Gaia hypothesis assumes that all human and natural systems are alive and hence have intrinsic values and rights. Human rights are extended to the natural realm in a process of logical projection. Such arguments also don't see the distinction between nature and culture; they conceive both realms as identical. As the arguments put forward by eco-fascism show such a projection can be very dangerous. E.g. Peter Singer argues that all persons understood in the sense of a person as a conscious thinking being have a right to live, other beings have not. Hence certain animals would have a right to live, whereas certain human beings such as disabled newborn infants, hemophiliac infants not wanted by their parents or adopters, any young infant not wanted by its parents or adopters, and all human beings who do not know they are persons. Singer argues in favour of euthanasia of such humans. "Killing a disabled infant is not morally equivalent to killing a person. Very often it is not wrong at all" (Singer 1993: 191). "Deep ecologists" like David Foreman argue that starvation and disease are "Gaian" solutions to overpopulation. "Human suffering resulting from drought and famine in Ethiopia is tragic, yes, but the destruction there of other creatures and habitat is even more tragic" (Foreman 1991). In an interview Foreman said that "the worst thing we could do in Ethiopia is to give aid [to the starving children] - the best thing would be to just let nature seek its own balance, to let people there just starve" (cited from Bookchin 1988). Such eco-fascist arguments are inhumane in nature, they don't see the differences between nature and human culture, they project human rights and human qualities like self-consciousness into nature; the latter is considered as one whole living organism ("Gaia"). "Words like commanding, exploitation, and hierarchy are actually social terms that describe how people relate to each other; applied to the natural world, they are merely anthromorphic. [...] When biocentrists, anti-humanists, and 'deep 
ecologists' flagellate us with claims that life-forms have 'rights' to life and self-realization that we, as humans, fail to recognize, they unknowingly participate in a hidden anthropomorphism that we bring to many forms of life" (Bookchin 1995: 30, 138f).

James Lovelock defined Gaia as "a complex entity involving the Earth's biosphere, atmosphere, oceans, and soil; the totality constituting a feedback of cybernetic systems which seeks an optimal physical and chemical environment for life on this planet“ (Lovelock 1979: 10). This hypothesis includes that "the entire range of living matter on Earth from whales to viruses and from oaks to algae could be regarded as constituting a single living entity" (Lovelock 1979: 9). Hence the difference in identity of living systems is lost here, all living systems are considered as equal parts of a super-organism termed Gaia. Also the specific difference and qualities of humans and society are not taken into account. Gaia is ecology's Stalinist productivism. "People denounce the idea of subordinating all individualist will to the unreasonable demands of Moloch Gaia - just as in the past socialism was reduced to Stalinism!" (Lipietz 1996: 327).

\section{2.3. Dualism}

Dualism conceives nature and society as non-identical and radically different. For Claude Lévi-Strauss (1981) the human being is both biological and social. He has conceived the relationship of nature and culture dualistically, seeing culture as everything that is not nature and that is opposed to the latter. Culture would be non-instinctive and based on norms and rules, whereas natural aspects of the human realm would be spontaneous, undetermined, and universal. Such a dualistic conception only sees the differences between nature and culture, it is blind for common aspects and the interactions of both realms. Speaking of the duality of nature and culture means to assume a very broad concept of culture that includes a wide range of social practices and structures. E.g. Marvin Harris (1997) puts forward such a broad concept of culture, culture here includes technologies, productive and reproductive activities, social groups and organizations, as well symbolic, ideational, artistic, playful, religious, and intellectual practices and structures. Hence there is nothing left outside of culture (except pure nature) within society and culture means society. No clear distinction between culture and society can be maintained. Therefore I think it is advantageous to assume that society is the broader concept, that we are confronted with a dialectic of nature and society, and that culture forms a specific self-organizing subsystem of society that is based on a mutual production of subjective ideas and objectified ideational, meaningful forms.

The dualistic division between nature and culture has frequently been ideologically employed for arguing that certain groups that don't have a Western culture are uncivilized and uncultivated and hence need to be adapted to Western ideas. Such assumptions that define Western society as culture and other societies as non-culture are ideologies that have during the course of human history been frequently employed as justifications for domination, exploitation, colonialism, and warfare.

Niklas Luhmann (2004) argues that a system forms its border by the system/environment-difference, that society is the all-enclosing social system of communications and that nature forms the environment of society. His approach is based on an ontology that considers systems as self-centred, endogenous, and closed, there are no causal relationships between systems, only irritations and disturbances. "The relationship of system and environment is constituted by the system's closing off its self-reproduction against the environment by internal circular structures and by being only exceptionally - only on other levels of reality - irritated, built up, and put into oscillation. We term this case resonance" (Luhmann 2004: 40). For Luhmann systems are not open, interconnected, in complex causal relationships, and in processes of exchange, contact between a system and its environment is only considered as an exception from the rule and as a very weak disturbance for the normal systemic functioning. Based on such a dualistic concept of system and environment, Luhmann can neither explain how ecological problems are caused nor how they could be solved, he is only interested in how society communicates about ecological 
problems (ecological communication) and argues that ecological problems are only problems because society communicates them as problems (Luhmann 2004: 63) which suggest a radical constructivist perspective that doubts the existence of real problems. In such an approach ecological problems are not real, but only constructed.

Christoph Görg (2001) argues that Luhmann has stressed in later works that nature and society are structurally coupled (Luhmann 1997: 130) and that hence Luhmann has accepted causalities between the two systems. Structural coupling does not imply a stronger form of causality than Luhmann's concept of resonance because this notion that stems from Maturana and Varela means that the environment can't determine structural transformations of a system, but can only cause perturbations. This concept operates like Luhmann's theory in terms of closed, autonomous, differentiated systems.

Luhmann's main argument is that modern society is functionally differentiated, i.e. it is organized in the form of autonomous subsystems where each fulfils a specific function that is based on a specific dual code and a specific programme. Such systems are operationally closed. He tries to show that none of these subsystems (he mentions economy, legal system, science, polity, religion, education, and ethics and devotes one chapter for each system) is responsible, appropriate, or competent for dealing with ecological problems or solving them because all of them would be concentrated on their own systemspecific problems and operations that would leave no place for external problems. In case of the economy Luhmann argues that this system is only interested in prices and hence deals only with ecological problems if they can be expressed in the language of prices. Luhmann simply ignores that the economy is the system where the metabolism between society and nature is organized and that the industrial form of economic production has resulted in global ecological problems. There simply seems to be no solution for ecological problems for Luhmann and he seems to be willing to accept them as irrevocable reality. Luhmann tells us that ecological problems are simply too complex to be solved by society and that problem solution by specific subsystems would be determined to fail because these systems would be functionally differentiated and would by attempting solutions try to act as centres of society which would generate new problems. Luhmann's systemic fatalism is ignorant and ideologically distorted. The Green movement and the New Social Movements earn only scorn and derision in Luhmann's account of ecological problems, he argues that they protest against functional differentiation, are self-righteous, lack theory, have no real solutions, name only enemies, stir up and communicate fears. In the end Luhmann argues that he doesn't want to explain how ecological communication could contribute to a solution of ecological problems and that there can be no privileged location in society that can formulate norms, rules, or guidelines for the solution of these problems (Luhmann 2004: 249). Luhmann's dualistic systemic approach can't explain how society and nature are related, how in modern society this relationship generates problems, and it doesn't contribute any insight to possible solutions. The function of Luhmann's theory for society is that it is completely useless. Luhmann's insight is that nothing can be done because society functions as it functions, he is blind for the insight that social and ecological problems are due to the antagonistic dysfunctions of modern society and that more far-reaching social changes are needed.

\section{2.4. Nature-society-dialectic}

A dialectical position sees nature and society both as identical and non-identical.

Matter is the totality of objects that constitute reality and is itself constituted in space and time by an interconnected totality of bodies that react on one another (motion), i.e. they repulse and attract each other. Motion is the mode of existence of matter in space-time. Matter is an eternal process of becoming and passing away; a ceaseless flux, it is uncreatable and indestructible. Matter is the totality of objective, really existing systems that are interconnected and accord to different physical laws. To argue that nature is dialectical allows explaining matter as dynamically and endlessly producing and organizing itself. Hence the assumption of God as an external creator of the world is rendered unnecessary. The material unity of the world means that the motion of matter results in a natural hierarchy of relatively autonomous forms of movement of matter where each level has new, emergent qualities that can't be reduced to lower levels or 
an assumed "materia prima". Time is an expression of the irreversible changing state of matter. Movement in time means movement in space and vice versa. Both space and time express the permanence of change that is a fundamental property of matter. Matter permanently organizes itself and produces an irreversible sequence of states.

Attraction and repulsion are the essence of matter (Hegel 1874: §§97-98), as polar opposites they are "determined by the mutual action of the two opposite poles on one another, [...] the separation and opposition of these poles exists only within their unity and inter-connection, and, conversely, [...] their inter-connection exists only in their separation and their unity only in their opposition" (Engels 1886: 357).

Theories of self-organization put forward a dynamic concept of nature. Self-organization is a process where a system reproduces itself with the help of its own logic and components, i.e. the system produces itself based on an internal logic. Self-organizing systems are their own reason and cause, they produce themselves (causa sui). In a self-organizing system new order emerges from the old system, this new order can't be reduced to single elements, it is due to the interactions of the system's elements. Hence a system is more than the sum of its parts. The process of the appearance of order in a self-organizing system is termed emergence. Concepts from self-organization theory such as control parameters, critical values, bifurcation points, phase transitions, non-linearity, selection, fluctuation and intensification in selforganisation theory correspond to the dialectical principle of transition from quantity to quality (Fuchs $2003 \mathrm{~b}, \mathrm{f})$. What is called emergence of order, production of information or symmetry breaking in selforganization theory corresponds to Hegel's notions of sublation (Aufhebung) and negation of the negation (ibid.). Self-organization theory can be considered as a reformulation of dialectical thinking, it conceives nature as complex, active, self-producing, and dynamic.

The self-organization of matter as an active and productive process produces different organizational levels of matter (such as physical matter, biological matter, and society) that are organized in a systemic hierarchy in which upper levels have new emergent qualities that distinguish them from lower levels. Hence there is an evolutionary hierarchy of matter that ascends from the abstract to the concrete; selforganization on upper levels is richer in qualities than on lower levels. Physical matter is self-structuring; it has the capability of spontaneously producing emergent patterns and new systems. Such processes have in self-organization theory been described e.g. by Nobel Prize winner llya Prigogine with the concepts of dissipative systems and order from noise and in Hermann Haken's Synergetics. Biological systems are self-structuring as well as self-reproducing; they permanently produce and reproduce their elements and their own systemic unity. In self-organization theory such systems have been termed autopoietic systems by Humberto Maturana and Francisco Varela. In both physical and biological self-organization we find entities that interact in such a way that new emergent qualities of a system or a new system as a whole emerge. This process can be conceived as a dialectic of elements and structures, i.e. a mutual productive process where interacting entities produce structures that enable and constrain further interactions that produce further structures, etc. (fig. 1). The difference between physical and biological systems is that biological systems are more dynamic, they permanently produce and reproduce patterns, whereas physical systems are less dynamic in the sense that novelty is not permanently created, but from time to time. Hence physical and biological systems are operating at different time scales. Note that the different levels of physical and biological self-organization are interconnected: systems of one level form elements that produce a new system on a higher level. Hence there is an interconnected hierarchy that includes e.g. atoms, molecules, macro-molecules, cells, tissues, organs, and organ systems. 


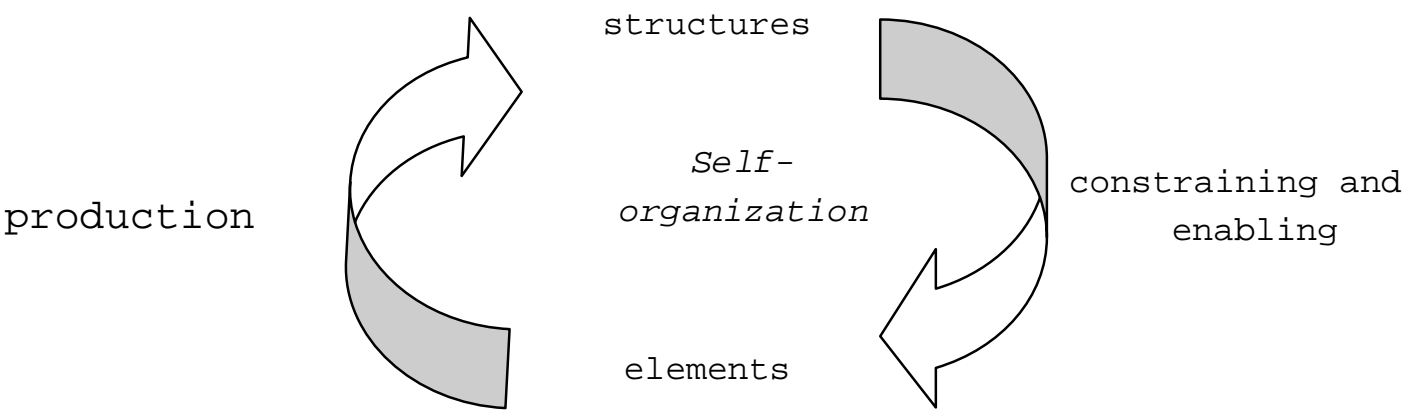

Fig. 1: Self-organization

Society is a level of the self-organization of matter that is characterized by active, self-conscious, creative, imaginative being. Social self-organization just as the physical and biological one is dynamic, self-referential, and circular, but self-conscious cognition, communication, and co-operation is the quality that makes a difference between society and nature. Society is a specific product of the self-organization of matter that accords to its own dialectical laws of movement and to a certain respect shares general dialectical principles.

As organizational level of matter society is part of nature, but it also possesses qualities that can't be found in biological and physical matter. Hence it is a higher-level system that encompasses and encapsulates parts of biological and physical nature. Those parts of nature that are appropriated by man form a specific subsystem of society, the eco-system, that encompasses the biological and physical environment of human societal activity. Society and culture are a sublation of nature, nature and society are dialectically connected. When we speak about nature we always speak about systems that are observed and changed by human beings, nature is part of society, for human beings there can be no observation of and encounter with nature from the outside of society. The relationship of nature and society/culture is neither exclusive nor inclusive in character, i.e. nature and society are neither fully different nor fully identical. Nature is the totality of systems in the universe and their interactions, it is material and organizes itself on various levels, i.e. it consists of various evolving, interconnected system types. Systems of one type are interconnected and connected to systems of other types; hence nature is relational and dynamic in character. Society is the realm of human activity and interaction; it forms one specific, small part of nature. But for human beings this small part of the universe forms their overall context of activity. All human activity and observation takes place within society, there is no position of humans external to society. Hence nature as physical realm of activity of human labour, production, and communication is itself a part of society, in transforming and observing nature in economic, technological, cultural, and scientific processes, the human being integrates nature into society. Hence there is no relationship between nature and human beings external to society, all metabolic and observational processes that establish a relationship between nature and human beings function within society. Nature as human realm of activity is one subsystem of society that can be termed eco-sphere. Nature has produced the human being and society, but the human being integrates (certain parts of) nature as a subsystem of society into its own sphere of activities. Hence when we speak about "nature and society" we speak about society as the total realm of activity on the one hand where we focus on social interactions between human beings and about the eco-sphere as the interaction processes between humans and ecology and the interaction processes between physical systems that are observed by human beings. Society is a sublation of nature, in production humans consume natural forces, hence nature is a foundation of society and continues to exist in society, and they transform nature in such a way that use values and social relationships emerge that have a specific social function that doesn't exist in nature as such. 
In the production of his life that includes the metabolism between society and nature and societal reciprocity, man as the universal, objective species-being produces an objective world and reproduces nature and his species according to his purposes. All human beings are naturally societal, within the human realm nature is social in the sense that it is being changed and appropriated by human beings. Within nature there are qualitative differences which allow a division into levels such as physical-chemical, the living and societal. In this relationship frequently only the physical-chemical and the living is seen as "nature" opposed to human society. We stress the unity in which the diversity is sublated, hence also preserved, nature and society are dialectically related (Fuchs/Schlemm 2005). Societality is our nature, nature is part of our society.

Society is a self-organizing system that is based on the mutual production and interconnection of social actors and social structures (figure 2, for a more detailed discussion cf. Fuchs 2003c, d). In this respect structures are medium and outcome of social actions, they both enable and constrain social actions. This idea corresponds to saying that social systems are re-creative, i.e. self-organizing social systems. Recreativity is based on the creative activities of human beings. Social structures exist in and through the productive practices and relationships of human actors. Structures are both structuring (human social practices) and structured (by human social practices). Social self-organization is a self-referential, cyclical, reflexive, interconnected, double-sided, dialectical process of mutual production. Social systems are a sublation of natural systems: they have qualities that they share with biological systems (self-reproduction, self-structuring) and physical systems (self-structuring) and they have emergent qualities that can neither be found in bio-systems nor in physical systems, i.e. they are based on creative human actions that can based on the enabling and constraining effects of human history make choices on how to creatively design social structures. Hence social systems are self-structuring, self-reproducing, and re-creative.

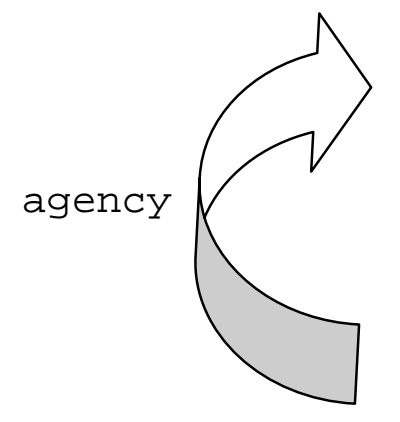

Figure 2: Societal self-organization

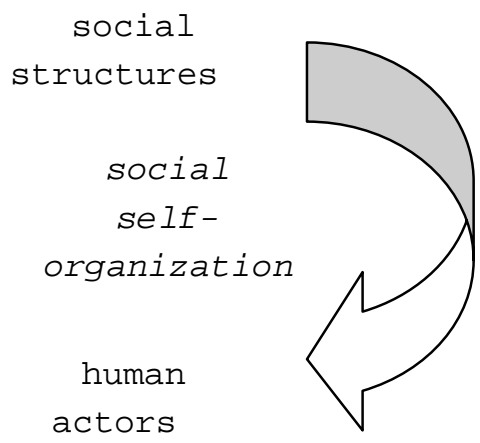

actors constraining and

enabling

Society is made up by a number of interconnected, encapsulated subsystems that fulfil specific roles and have specific practices and structures: the eco-sphere, the techno-sphere, and the socio-sphere. The socio-sphere is the system where social relationships and social meaning are produced, it consists of three interconnected, encapsulated subsystems: economy, polity, and culture (Fuchs 2003e). The technosphere is the system of society where human beings design and apply technological tools and capabilities in order to simplify their existence. The eco-sphere is the subsystem of society where humans use tools in order to appropriate nature, in this subsystem physical and biological systems form a life support system of society. The techno-sphere is the system that mediates between socio-sphere and eco-sphere, i.e. technologies are means that are produced and applied by humans in order to transform and appropriate nature, to satisfy human needs, and to simplify human life.

Society (or the socio-sphere) and nature (in the sense of the eco-sphere, i.e. that part of biological and physical matter/nature that is socially constructed and appropriated by humans) are interconnected. This interconnection has already been stressed by Marx and Engels: "We know one science alone, the science of history. History can be examined from two aspects and divided into the history of nature and the history 
of man. But it is impossible to separate these two aspects from one another. So long as men exist the history of nature and human history will condition one another" (Marx/Engels 1846: 18). Matter that is not observed and transformed by humans is not relevant for society, hence for sociological analysis we are interested in those parts of nature that are socially constructed and appropriated. "But nature too, taken abstractly, for itself - nature fixed in isolation from man - is nothing for man" (Marx 1844: 587).

The self-organization cycle of nature (fig. 1) and the self-organization cycle of the socio-sphere (fig. 2) are mutually connected in a productive cycle where natural self-organization serves as the material foundation that enables and constrains social self-organization and human production processes transform natural structures and incorporate these very structures into society as means of production (technologies, raw materials) (cf. fig. 3). "The economic process of reproduction, whatever may be its specific social character, always becomes intertwined in this sphere [...] with a natural process of reproduction" (Marx 1885: 359). Nature can exist and self-organize without society, society can't exist and self-organize without a natural base, the eco-sphere as the socially constructed part of nature is shaped and transformed by society. The economy is that part of the socio-sphere where the relationship between nature and the socio-sphere is established: In the economic system nature is appropriated in the form of means of production that are applied and transformed by human labour in such a way that use values that satisfy human needs are produced and can be distributed, circulated, and consumed. Hence it makes sense to argue that the economy is more material and fundamental in character than polity and culture and that it forms together with the eco-sphere and the techno-sphere the material foundation of society. In the relationship of nature and society, human actors (society) form objective structures, they externalize and objectify their labour power in social processes that result in material objects (use-values). Hence the process of the production of use-values is a process of objectification of the subjective. Nature as objective material being enters society in the form of raw materials, technologies, and use-values that are consumed as the foundation of production that is appropriated by nature and incorporated into human labour practices and experiences. Hence this process is a process of subjectification of the objective/material. The whole self-organization cycle that connects society and nature hence is based on a dialectic of the subjective (labour power, social relationships) and the objective (natural forces, technologies, raw materials, use values), the objectification of the subjective and the subjectification of the objective. The socio-sphere can be considered as the subjective and the ecosphere as the objective aspect of the society-nature-system.

That society is based on and connected to nature has been grasped by Vernadsky's concept of the biosphere: "In the thick of life today, intense and complex as it is, a person practically forgets that he, and all of mankind, from which he is inseparable, are inseparably connected with the biosphere - with that specific part of the planet, where they live. It is customary to talk about man as an individual who moves freely about our planet, and freely constructs his own history. Hitherto neither historians, scientists in the humanities, nor, to a certain extent, even biologists have consciously taken into account the laws of the nature of the biosphere - the envelope of Earth, which is the only place where life can exist. Man is elementally indivisible from the biosphere. And this inseparability is only now beginning to become precisely clear to us. In reality, no living organism exists in a free state on Earth. All of these organisms are inseparably and continuously connected - first and foremost by feeding and breathing - with their material-energetic environment. [...] Mankind, as living matter, is inseparably connected with the materialenergetic processes of a specific geological envelope of the Earth - its biosphere. Mankind cannot be physically independent of the biosphere for a single minute" (Vernadsky 1945). Nature as the material environment of man forms the biosphere/eco-sphere of society. It is important to note that Vernadsky with his concept of the biosphere merely suggests an inherent connection of society to nature, he does not suggest like Lovelock in his Gaia hypothesis that man and society form yet another identical part of a super-organism. Hence it is important to stress the identity in difference and difference in identity of the biosphere and society, society is a sublation of the biosphere. 

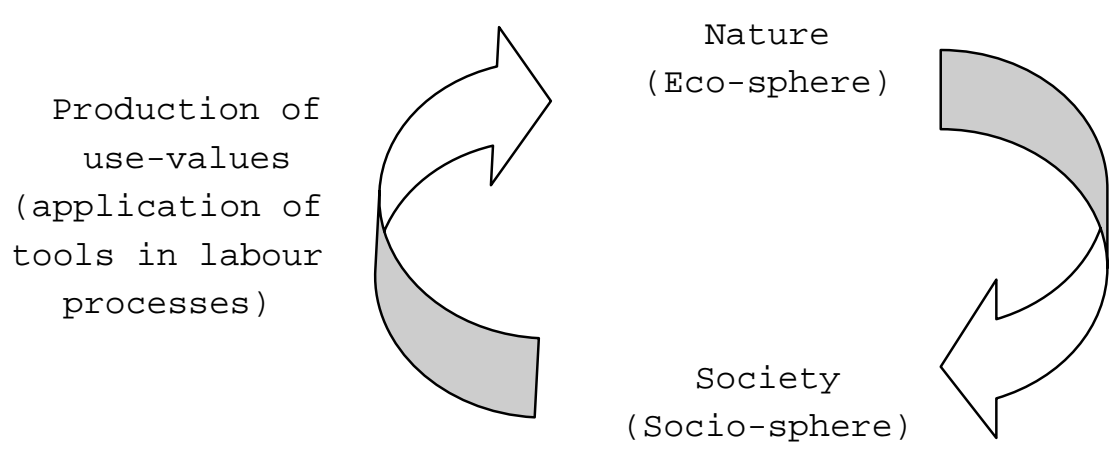

Figure 3: The dialectical relationship of nature and society

A dialectical view on nature/society assumes that nature is the foundation of society, that there is a continuous metabolism between nature and society, and that society has emergent qualities that distinguish it from nature. Marx pointed out that man like animals lives from inorganic nature, he must remain in a continuing physical dialogue with nature in order to survive. Nature can be considered as man's inorganic body in the sense that nature is "a direct means of life" and "the matter, the object, and the tool of his [man's] life activity" (Marx 1844: 516). "The earth is the great workshop, the arsenal which furnishes both means and material of labour, as well as the seat, the base of the community" (Marx 1857/58: 384). For Marx the human being is a species-being - not only in the sense that he reproduces the species biologically, but also in the sense that he lives from inorganic nature and natural products. "Nature is man's inorganic body - that is to say, nature insofar as it is not the human body. Man lives from nature - i.e., nature is his body - and he must maintain a continuing dialogue with it if he is not to die" (Marx 1844: 516. cf. also Marx 1857/58: 386; Marx also speaks of nature as man's "extended body" (Marx 1857/58: 399)). "Nature becomes one of the organs of his activity, one that he annexes to his own bodily organs, adding stature to himself in spite of the Bible" (Marx 1867: 194). "All production is appropriation of nature on the part of an individual within and through a specific form of society. [...] in production the members of society appropriate (create, shape) the products of nature in accord with human needs" (Marx 1857/58: 23f). Hence nature is a foundation of society, it is part of society. But also society is a part of nature: "To say that man's physical and mental life is linked to nature simply means that nature is linked to itself, for man is a part of nature" (Marx 1844: 516). Engels has stressed that there are both effects of nature on man and the change of nature by man (Engels 1886: 498).

For Marx man's relationship to nature is twofold (subjective, objective): "These natural conditions of existence, to which he relates as to his own inorganic body, are themselves double: (1) of a subjective and (2) of an objective nature. He finds himself a member of a family, clan, tribe etc. - which then, in a historic process of intermixture and antithesis with others, takes on a different shape; and, as such a member, he relates to a specific nature (say, here, still earth, land, soil) as his own inorganic being, as a condition of his production and reproduction" (Marx 1857/58: 398).

The animal produces only its own immediate needs, whereas man (re)produces himself and the whole of nature universally and this results in the practical human creation of an objective world. Modern society has estranged man from himself and nature, this results in the exploitative appropriation of both, life has become alienated life. Marx has described man as a self-reproducing being: this does not only mean the internal autopoietic self-reproduction of the organism as suggested by Maturana and others, it also means an external, social as well as natural type of self-reproduction: man reproduces himself by social activities and by exchanging matter and energy with his natural environment (=labour). Material production, social activities and a relationship between man and nature are necessary for the self-reproduction of man and 
the reproduction of the whole of society and nature by human activities. The aspect of the conscious reproduction of the man-nature-relationship is grasp by the concept of the species-being.

Human beings exchange matter and energy with their natural environment. Labour is a social process that results in the production of use-values and social resources that are useful for humans, satisfy human needs and are produced in order to simplify existence and achieve defined goals. Labour is only possible as an active shaping of nature and the world, man appropriates nature in order to produce use values. Labour is a "special productive activity, exercised with a definite aim, an activity that appropriates particular nature-given materials to particular human wants. So far therefore as labour is a creator of use value, is useful labour, it is a necessary condition, independent of all forms of society, for the existence of the human race; it is an eternal nature-imposed necessity, without which there can be no material exchanges between man and Nature, and therefore no life" (Marx 1867: 57). "As useful activity directed to the appropriation of natural factors in one form or another, labour is a natural condition of human existence, a condition of material interchange between man and nature, quite independent of the form of society. On the other hand, the labour which posits exchange-value is a specific social form of labour" (Marx 1859: 23f). "Labour is, in the first place, a process in which both man and Nature participate, and in which man of his own accord starts, regulates, and controls the material re-actions between himself and Nature. He opposes himself to Nature as one of her own forces, setting in motion arms and legs, head and hands, the natural forces of his body, in order to appropriate Nature's productions in a form adapted to his own wants. By thus acting on the external world and changing it, he at the same time changes his own nature." (ibid.: 192). Nature is the "universal subject of human labour" (Marx 1867: 193), it is the "sensuous external world. It is the material in which his labour realizes itself, in which it is active and from which, and by means of which, it produces" (Marx 1844: 512).

Man forms nature by changing the form of matter in labour processes, both the labour exercised on natural forces and natural forces that form a foundation of labour are conditions of material wealth. Based on a certain socially shaped state of nature (nature is social) ${ }^{1}$, labour transforms with the help of tools certain parts of nature (society is (among other things) natural, i.e. it is based on nature) in order to gain products that represent a transformed state of both society and nature. It is in this sense that one can say that man is an active natural being (cf. Marx 1844: 578). The relationship between man and nature is mediated by technologies. Humans produce technologies in order to better organize the labour process. Technology can be defined as a purposeful unity of means, methods, abilities, processes and knowledge that are necessary in order to achieve defined goals. Humans have the ability to consciously think about their environment, to set themselves self-defined goals and to find different ways to achieve these goals. Technologies mediate the reaching of human goals and the social labour process, man is a "toolmaking animal" (Marx 1867: 194).

Humans make use of objects in the world and they actively create new objects in the labour process. Hence man is objective man. In this process, his living labour power is being objectified in use values that are a type of dead labour that store information about the world and society. This objectivity of human existence also finds an expression in the fact that all human organs and senses are in their orientation to the object, the appropriation of the object, the appropriation of human reality (Marx 1844: 539). So the objective world becomes the world of man's essential powers for man in society and "all objects become for him the objectification of himself, become objects which confirm and realise his individuality, become his objects: that is, man himself becomes the object" (Marx 1844: 541). Man is a corporeal, living, real, sensuous, objective being that has real, sensuous objects as the object of his being, he can only express his life in real, sensuous objects.

\footnotetext{
1 "Man, who produces in society, likewise faces an already modified nature (and in particular natural factors which have been transformed into means of his own activity) and definite relations existing between the producers. This accumulation is in part the result of the historical process, in part, as far as the individual worker is concerned, transmission of skill“ (Marx 1862/63 (3): 289).
} 
Nature enters the economy in the form of means of production (natural forces, technological tools, raw materials, auxiliary materials). The economic system is based on the dialectical relationship of productive forces and relations of production. Relations of production describe the ways of social mediation between humans that act as agents or as (opposed or co-operating) social groups in economic processes. The productive forces are a systemic totality of living labour force and factors that influence labour. Living labour and its factors form a relationship that changes historically and is dependent on a concrete formation of society (such as capitalism). The influencing factors can be summed up as subjective ones (physical ability, qualification, knowledge, abilities, experience), objective ones (technology, science, amount and efficacy of the means of production, co-operation, means of production, forms of the division of labour, methods of organization), and natural ones. These forces can only be viewed in their relationship to living labour. The system of productive forces can't be reduced to these forces, the system is only possible in combination with human labour. It is more than the sum of its parts, it is an integrated whole that lies at the foundation of economic processes.

Generally speaking, one can say that human beings make use of (subjective, objective, natural) productive forces as foundation of production processes, they employ tools in order to enter a metabolism with nature that results in the change of the material state of nature. As a result nature is appropriated, differentiated and transformed into a social fact, i.e. labour power produces economic goods with the help of productive forces that enable and constrain human economic practices, i.e. use values that satisfy human needs emerge. The production of economic resources takes places within specific social relationships, i.e. relations of production that have a specific historical form such as in capitalism the relationship between wage labour and capital that is a form of dependence and organized with the help of the wage-labour nexus. Produced economic goods are distributed and consumed, thereby they enter the system of the productive forces and function as part of the foundational system of human labour. Hence the whole process takes on the form of a productive cycle that interconnects productive forces and relations of production in such a way that in the economic system of society we find the permanent emergence of economic resources from human labour practices (cf. fig. 4). Hence the economic system is a dynamic system.

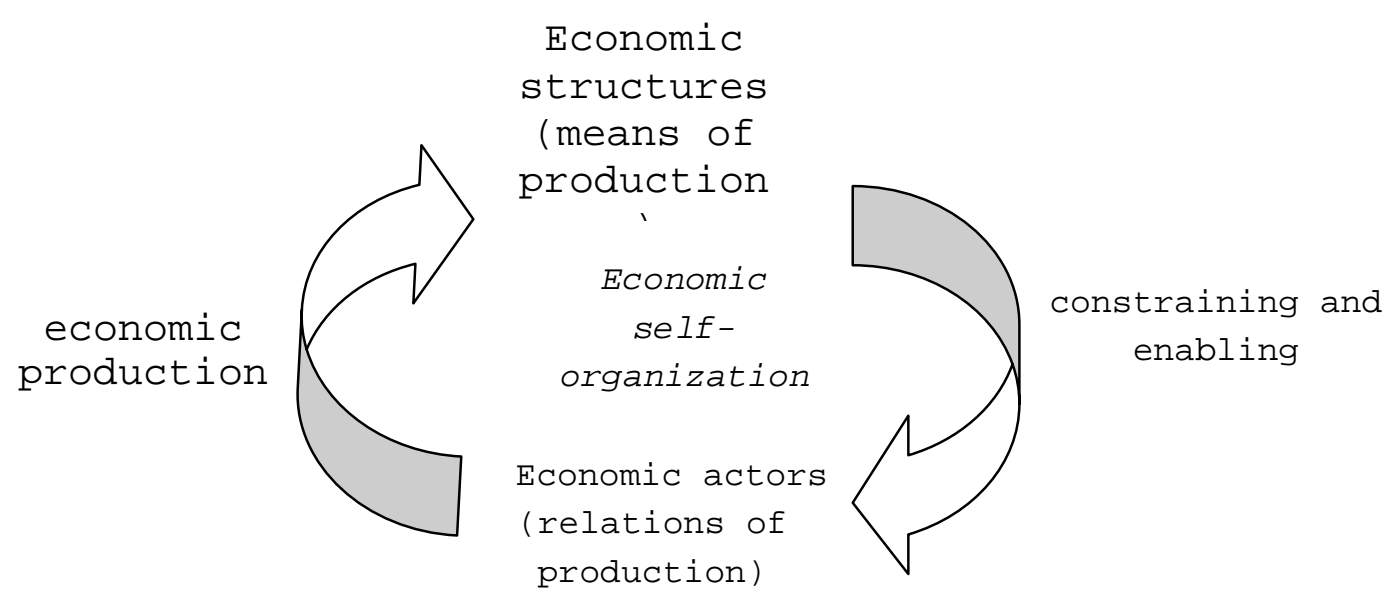

Figure 4: The process of economic self-organization

My own approach on science and nature stands in the dialectical tradition of Marx and Engels and conceives the relationships as both non-identical and identical: There are common aspects of nature and society, parts of nature are socially constructed and appropriated and function as material foundation of society, but society is also different from nature in so far as it is a system of self-conscious, active, creative, anticipatory, imaginative production. I will now argue that the dialectic of nature and society in modern society has become a fundamental antagonism that produces ecological problems. The mere contradiction of nature and society, the differential unity and united difference of both, has in modernity 
taken on the form of an enemy relationship that is due to the destructive effects of modern industrialism and the logic of accumulation.

\section{II.3. Nature and Modern Society}

Since the $15^{\text {th }}$ century Enlightenment thinking which forms the heart of the ideology of modernism has considered nature mainly as a machine, passive, inert, and a thing that needs to be controlled and mastered by man. Society and nature have been considered as two separate realms. "For the first time, nature becomes purely an object for humankind, purely a matter of utility; ceases to be recognized as a power for itself; and the theoretical discovery of its autonomous laws appears merely as a ruse so as to subjugate it under human needs, whether as an object of consumption or as a means of production" (Marx 1859: 323). The enlightenment caused a movement from magic to science, ritual to technology, belief/religion to reason - from nature to society. This shift in ideology was accompanied by the shift from agricultural society to industrial society, man was separated from nature and land and the working class as a propertyless industrial social group emerged.

Economy, polity and culture are in modern society based on accumulation and asymmetrical flows, the accumulation of capital, power and hegemony. These accumulation processes are autopoietic or selfproducing in the sense that the system reproduces itself by increasing the quantitative amount of one of its elements, i.e. it transforms its elements and herewith creates its unity. The economic system takes on the form of capital accumulation, i.e. economic self-organization in capitalism means the self-expansion and self-creation of capital based on the extraction of surplus labour (Fuchs 2004, Fuchs/Schlemm 2005). Economic goods take on the form of commodities, their character in the economy is determined by their exchange value, relations of production take on the form of class relations.

Like in all societal formations, in capitalism goods are produced that satisfy human needs. The specific ways this is done distinguish different societal formations. In capitalism the production process is based on the fact that economic actors produce goods which are sold on the market after their production in order to achieve a profit that allows re-investment, more production, the selling of more commodities, hence again more profit, etc. Marx called this process the accumulation of (money and commodity) capital. Capitalist production doesn't satisfy immediate needs (as was e.g. the case in the production of the medieval craftsman), but each capitalist is in need of the so-called "anonymous market" for the socialization of products. That the single capitalist enterprise produces in an isolated way, is of course not something biologically given, but a societal relationship. Marx is speaking of private labour that produces commodities. Another foundation of capitalism has been the detachment of the means of production from the workers. Marx is speaking of "double free wage-labour", the workers don't own the means of production and the produced goods and they are forced to sell their labour power (Marx 1867: 181-183). Wage labour and the industrial division of labour (which has been enabled by machine technologies, Marx speaks of machine-systems, large industry or the co-operation of many similar machines that are powered by a motor mechanism such as the steam engine, see Marx 1867: chapter 13) are necessary conditions for the full development of capital accumulation.

Capital accumulation is an autopoietic cycle that has been described by Marx as the expanded reproduction cycle of capital in his labour theory of value. The starting point is money capital that forms a social relationship. The capitalist buys with his money $(\mathrm{M})$ the commodities $(\mathrm{C})$ labour power $(\mathrm{L})$ and means of production $(\mathrm{Mp})$. This means that here a relation between relations of production and the productive forces is established (upward arrow in fig. 4). The means of production are considered in their value form as constant capital (c) and can be subdivided into circulating constant capital (the value of the utilized raw materials, auxiliary materials, operating supply items, and semi-finished products) and fixed constant capital (the value of the utilized machines, buildings and equipment) (Marx 1885: chapter 8). The value of the employed labour power is termed variable capital $(v)$. Constant capital is transfused to the 
product, but it doesn't create new value. Only living labour increases value - labour produces more value than it needs for its own reproduction. In production due to the effects of living labour onto the object of labour surplus value (s) is produced. This means that in the system of productive forces an auto-creative process takes place: living labour (i.e. human subjects) makes use of the objective, material part of the system in order to produce something new, a new good emerges. This good is more than the sum of the parts of the old system. A surplus that is due to living labour power is objectified in it. This creative process is itself a self-organization process within the overall economic autopoietic cycle, something new emerges. The value of a produced commodity $C^{\prime}=c+v+s$, this value is larger than the value of the invested capital $(C=C+v)$. The difference of $C^{\prime}$ and $C(\Delta C)$ exists due to the production of surplus value and is itself surplus value. Surplus value is transformed into profit (surplus value is "realized") and value into money capital by selling the produced commodities on the market. The transformation of the surplus value of the product into profit means that the product as a new emergent property of the system of productive forces is transformed into a commodity (downward arrow in fig. 4). This means that the overall economic self-reproduction has resulted in the self-transformation of the system, the accumulation of capital.

This autopoietic process is based on exploitation, alienation, and estrangement. In capitalism social structures are alienated social structures, they aren't controlled by their immediate producers, but are structures of the dominating groups. They are imposed on the individuals as interest "alien" to them and are to a certain extent independent of them in the sense that they can't control them. This is not only true for the economy, but for all realms of modern society. The self-reproducing (i.e. self-increasing, selfvalorizing, self-expanding) cycle of capital just outlined exists in and through agency: The actors enter social relationships and produce emergent properties within them. The social forces are a materialization of the social relationships that individuals enter. Together these two moments are structural components of a social system. These structural moments are based on human action and can only reproduce themselves autopoietically by reflexive actions that are enabled and constrained by the reproduced structures.

"Apart from the degree of development, greater or less, in the form of social production, the productiveness of labour is fettered by physical conditions. These are all referable to the constitution of man himself (race, etc.), and to surrounding nature. The external physical conditions fall into two great economic classes, (1) Natural wealth in means of subsistence, i.e., a fruitful soil, waters teeming with fish, and (2), natural wealth in the instruments of labour, such as waterfalls, navigable rivers, wood, metal, coal, etc." (Marx 1867: 535). Nature enters the economic accumulation process as material input in the form of means of production (constant capital): machines, raw materials, auxiliary materials. Machines are a transformation of natural forces and materials by human labour and scientific knowledge in such a way that nature can constantly and repeatedly by employed by humans in order to simplify and rationalize labour processes. Technologies save human energy, they economize the labour process. In the case of raw materials and auxiliary materials nature enters the production process in a more unmediated and direct way than in the case of technology. But in any form that nature enters production it is already a product of human labour, raw and auxiliary materials and technologies are at the same time result and conditions of labour processes. Instruments of labour show "traces of the labour of past ages" (Marx 1867: 196). Raw materials can either be the principal substance of a product or function as accessory/auxiliary material: "Raw material may either form the principal substance of a product, or it may enter into its formation only as an accessory. An accessory may be consumed by the instruments of labour, as coal under a boiler, oil by a wheel, hay by draft-horses, or it may be mixed with the raw material in order to produce some modification thereof, as chlorine into unbleached linen, coal with iron, dye-stuff with wool, or again, it may help to carry on the work itself, as in the case of the materials used for heating and lighting workshops. The distinction between principal substance and accessory vanishes in the true chemical industries, because there none of the raw material re-appears, in its original composition, in the substance of the product" (Marx 1867: 196). 
Labour to a certain extent also directly extracts natural resources, i.e. natural resources are in some production processes also a result of production that Marx terms "subjects of labour" (Arbeitsgegenstände) and differs from instruments of labour. "All those things which labour merely separates from immediate connexion with their environment, are subjects of labour spontaneously provided by Nature. Such are fish which we catch and take from their element, water, timber which we fell in the virgin forest, and ores which we extract from their veins. If, on the other hand, the subject of labour has, so to say, been filtered through previous labour, we call it raw material; such is ore already extracted and ready for washing. All raw material is the subject of labour, but not every subject of labour is raw material: it can only become so, after it has undergone some alteration by means of labour. An instrument of labour is a thing, or a complex of things, which the labourer interposes between himself and the subject of his labour, and which serves as the conductor of his activity" (Marx 1867: 193f).

Nature organized in the form of technologies increases productivity and hence cheapens commodities insofar as it replaces labour: "The machine costs [labour]. Natural agents as such cost nothing. They cannot, therefore, add any value to the product; rather they diminish its value in so far as they replace capital or labour, immediate or accumulated labour. In as much as natural philosophy teaches how to replace human labour by natural agents, without the aid of machinery or only with the same machinery as before (perhaps even more cheaply, as with the steam boiler, many chemical processes etc.), it costs the capitalist, and society as well, nothing and cheapens commodities absolutely" (Marx 1862/63 (2): 554, see also 556). The reason why capital is enthusiastic about the organization of nature in the production process in the form of technology is that it increases the productivity of labour and hence reduces the costs of variable capital (total amount of wages) and increases the speed of the production of surplus value: "So far as the powers of nature indicated by Ricardo are concerned, it is true that these are partly to be had for nothing and do not cost the capitalist anything. Coal costs him something, but steam costs him nothing so long as he gets water gratis. But now, for example, let us take steam. The properties of steam always exist. Its industrial usefulness is a new scientific discovery which the capitalist has appropriated. As a consequence of this scientific discovery, the productivity of labour and with it relative surplus-value rose. In other words, the quantity of unpaid labour which the capitalist appropriated from a day's labour grew with the aid of steam. The difference between the productive power of steam and that of the soil is thus only that the one yields unpaid labour to the capitalist and the other to the landowner, who does not take it away from the worker, but from the capitalist. The capitalist is therefore so enthusiastic about this element 'belonging to no one'" (Marx 1862/63 (2): 38).

Nature as capital in accumulation processes doesn't produce new value, its value is transfused to commodities by human labour that creates surplus value. It has been termed constant capital by Marx because it doesn't create new value in the production process. Raw and auxiliary materials get used up in single stages of production, all of their value instantly enters the commodity, whereas machines are employed for a longer time period in production, their value gradually enters commodities. Machines are fixed in the production process for a certain time, hence Marx terms them along with buildings and equipment fixed constant capital, raw materials are more fluid and dynamic, hence Marx terms them circulating constant capital. "The coal burnt under the boiler vanishes without leaving a trace; so, too, the tallow with which the axles of wheels are greased. Dye stuffs and other auxiliary substances also vanish but re-appear as properties of the product. Raw material forms the substance of the product, but only after it has changed its form. Hence raw material and auxiliary substances lose the characteristic form with which they are clothed on entering the labour-process. It is otherwise with the instruments of labour. Tools, machines, workshops, and vessels, are of use in the labour-process, only so long as they retain their original shape, and are ready each morning to renew the process with their shape unchanged. And just as during their lifetime, that is to say, during the continued labour-process in which they serve, they retain their shape independent of the product, so, too, they do after their death. The corpses of machines, tools, workshops, etc., are always separate and distinct from the product they helped to turn out. If we now 
consider the case of any instrument of labour during the whole period of its service, from the day of its entry into the workshop, till the day of its banishment into the lumber room, we find that during this period its use-value has been completely consumed, and therefore its exchange-value completely transferred to the product" (Marx 1867: 217f). "For some means of production (like living instruments of nature, e.g. horses) the reproduction is timed by nature itself, i.e. by their lifetime. Such elements can only be replaced entirely, other elements of fixed capital like machines can be renewed piecemeal. The wear and tear of fixed capital is partly caused by the action of natural forces, partly it is a result of use and partly it's the consequence of moral depreciation" (Marx 1885: 170f).

Capital accumulation is based on constant and variable capital as inputs of production, hence it consumes natural resources as raw materials (both in the form of principal substances of goods and accessory raw materials) and the longer it continues to be oriented primarily on surplus value and profit, non-renewable resources will continue to diminish. The goods produced in these processes are partly returned to nature after consumption in the form of non-recyclable waste. Waste and scarcity of natural resources cause costs for society, but capital normally doesn't pay for these results of capitalist production, hence it can increase profit by omitting expenditures for ecological restoration and putting these burdens on society. Capital is keen on reducing the costs of labour, nature, transport, rent, health, education, etc. in order to lower its investment costs which in turn increases profit. Nature in the form of raw materials functions as cheap or free resources for the economy, a heightened rhythm of capital formation results in increased consumption of nature and production of waste. Capital expands itself by technological progress, i.e. by increasing productivity, i.e. a certain amount of employed labour is able to process a larger quantity of raw materials in a shorter time period than at earlier historical stages of production. Capital is blind for ecological degradation as long as it is allowed to maximize profit by externalizing ecological costs or the conservation of nature doesn't take on a commodity form that allows the creation of new spheres of capital accumulation. "Capitals will minimize waste, recycle by-products, use energy efficiently, protect soil quality and forests, and so on, when it pays, otherwise not, except under duress" (O'Connor 1998: 204). As a result of economic accumulation processes, there is an increase of the mass of constant capital and a decrease of the mass of variable capital, i.e. the organic composition of capital increases and natural resources are continuously appropriated at an increasing pace. Ecological degradation impairs both society and the economy, capital accumulation is shortsighted and oriented on profit, hence it externalizes the costs of ecological destruction to society and nature.

Modern industrialism is unsustainable in two ways: 1. Accumulation processes result in the depletion of non-renewable natural resources; limits to extraction and accumulation are herewith created. 2. Economic production and consumption result in residues of goods that are shoved into nature by society in the form of waste. Hence ecological degradation includes both depletion and pollution. Based on figure 3 one can describe ecological degradation as a double process of the depletion of nature (in the direction where nature is appropriated by society) and the pollution of nature by society (in the direction where society transforms nature) (cf. fig. 5). Unsustainable ecological development is a process where depletion and pollution of nature by society cause the breakdown of more and more material (living and non-living) cycles of self-organization in nature and create threats to the survival of the whole eco-system that forms the material foundation of society. Hence the destruction of nature also threatens the survival of society and humankind. 


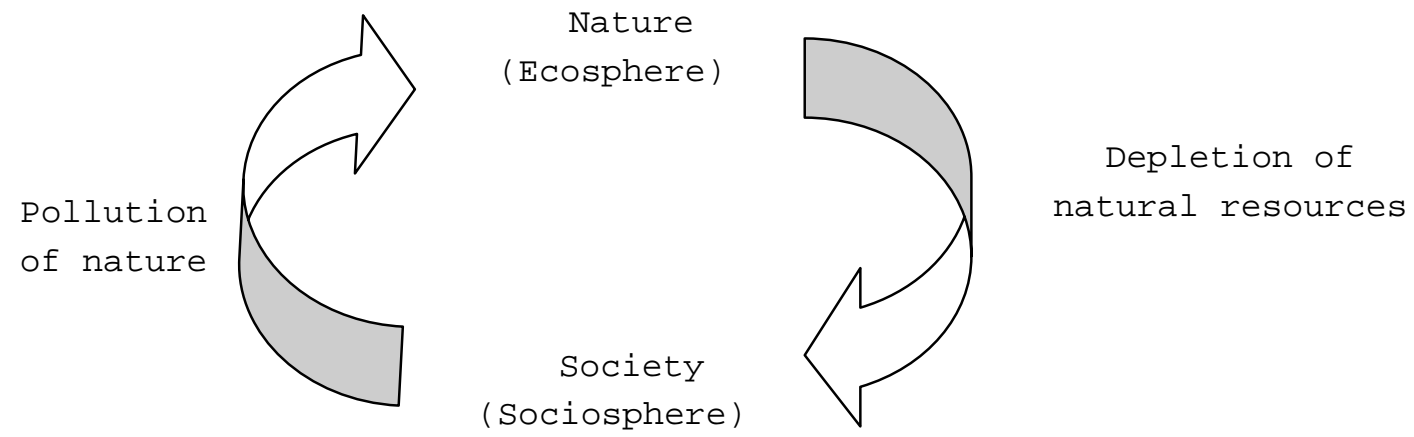

Figure 5: Unsustainable ecological development

Just like capitalism gives more value to profit than to human life, it also gives more value to profit than to nature. Capitalism destroys both the life of human beings who are reduced to function as labour power that doesn't control its own products and have to a certain extent work for free in order to survive and of nature that forms the material foundation of human life processes. Hence there is a double impairment of the life of exploited persons and groups, they are confronted by precarious social conditions and have to bear the effects of the destruction of the ecosphere whereas the economically well-off classes can buy both undamaged social and natural conditions and enjoy a good life.

Complexity theory shows that small causes can have large, unforeseeable effects (butterfly effect) and can spread like a snowball. This insight is relevant for the relationship of nature and society (Lipietz 1996: 328, Luhmann 2004: 98f) because it means that the dominant form of production has produced uncertainties and risks that threaten to get completely out of hand and at a certain unpredictable moments causes ecological disasters that result in the breakdown of social systems. Modern ecological disaster like Chernobyl, Mad Cow Disease, or the ozone-hole have a global character, they quickly spread and show that high-risk technologies and high-risk behaviour cause complex uncertainties. This implies that humans have to limit and reverse their negative influences on nature in order not to risk creating further selfexpanding disasters that threaten humanity.

James O'Connor (1998) has argued that besides a contradiction between productive forces and production relations that takes on the form of a contradiction between production and realization of value there is a "second contradiction of capitalism" (O'Connor 1998: 158-177), "the contradiction between capitalist production relations (and productive forces) and the conditions of capitalist production, or 'capitalist relations and forces of social reproduction'" (O'Connor 1998: 160). I have argued that capitalism is a complex system and that its crises are not due to a singular antagonism and can't be reduced to the economy (Fuchs 2002, 2004), they are based on a set of fundamental economic, political, and cultural antagonisms (in the case of the economy these are antagonisms such as the ones between necessary and surplus labour, use value and exchange value, productive forces and relations of production, living and dead, objectified labour, single production and social need, production and consumption, socialized production and private appropriation, producers and means of production) that interact and have no fixed structure of interaction. Hence I don't agree with O'Connor's economic analysis because I find it too simplistic and reductionistic and doubt that there is only one or that there only two contradiction(s) of capitalism. But he makes an important point by stressing that there is an antagonism between natural forces and the mode of production. I would add that this is not only a capitalistic antagonism, but one that has shaped the entire formation of modern society that has been based on a mode of production that has been made up by a destructive form of industrialism. Both the economy of capitalism and the Soviet system have been shaped by this "ecological antagonism". 
Since the rise of the Fordist mode of capitalist development that was based on mass production, mass consumption, the standardization of production, corporate hierarchy and centralization, Keynesian economic policies, standardized production and goods, the welfare- and intervention-state massive increases in productivity, consumption, and the material throughput of developed economies have been achieved. The Fordist production model that originated in the West and was copied by the Soviet Union is one of the major causes of the global ecological crisis. "Alongside the economic crisis [of the 1970s], a quite novel form of ecological crisis - the crisis of abundance - was making itself known. It was the tainted legacy of the post-war economic miracles. In the OECD area, technical progress had at last made it possible to feed humankind, but at the price of a dangerous impoverishment of biodiversity and landscape variety. Town-dwellers, crowded into megacities, had discovered traffic jams and pollution as the cost of their mobility. Morbidity and mortality were increasingly being related by epidemiology to, not underconsumption, but excessive consumption of certain things. More generally, the industrial model was threatened by a new scarcity of natural resources - not so much, as the Club of Rome had feared, in terms of raw materials as in terms of the planetary ecosystem's capacity to recycle wastes" (Lipietz 1999). André Gorz $(1977: 21,72,81)$ stresses that industrial growth has resulted in pollution of nature and shortage of natural resources and that hence capital has to invest in environmental protection which would negatively influence profit rates and would have contributed to the crisis of Fordism. The organic composition of capital and the share of constant capital would rise due to the ecological crisis and the reparation work required. As an effect either profit rates would fall or capital would have to increase prices which in turn would lower demand and hence advance economic crisis. In both cases the ecological crisis would impair economic growth and advance economic crisis. Also Immanuel Wallerstein has argued that the ecological crisis contributes to economic crisis: "Now while the cost of purchase is normally borne entirely by the firm that will eventually get the profits, the costs of treating the materials is often partially borne by others. For example, if in treating the raw materials, there is toxic or cumbersome waste, part of the cost involved is getting rid of such waste, and if toxic, in a safe manner. Firms of course desire to minimize these costs of disposal. One way they can do thus, a way very widely practiced, is by placing the waste somewhere away from the factory site after minimal detoxification, for example, by dumping chemical toxins into a stream. This is called by economists "externalizing the costs." Of course, this is not the end of the costs of disposal. To stick to the example, if toxins are dumped into a stream, this may poison the stream, and eventually (perhaps decades later) there will be damage to people or to other matter (at costs that are real, if difficult to calculate). And there may be a social decision to clean up the toxins, in which case the body that undertakes the clean-up, often the state, is bearing the cost. Another mode of reducing costs is to utilize raw materials, but not to provide for (that is, pay for) their renewal, a problem especially true of organic matter. Such externalization of costs significantly reduces the costs of raw materials to given producers and hence increases the margin of profit. The problem here is akin to that with relocation as a solution to wage costs. It works as long as there are previously unutilized areas in which to dump waste. But eventually there are no more streams to pollute, or trees to cut down - or at least, there are no more without serious immediate consequences for the health of the biosphere. This is the situation in which we find ourselves today after 500 years of such practices, which is why today we have an ecology movement that has been growing rapidly throughout the world. What can be done? Well, the governments of the world can undertake what amounts to a vast clean-up campaign and a vast campaign of organic renewal. The problem is the cost of an effective operation, which is enormous, and thus must be paid by someone via some form of taxes. There are only two someone's: either the firms that are considered to have been the perpetrators of the waste, or the rest of us. If it is the former, the pressure on the profit margins will be impressively high. If it is the latter, the tax burdens will mount significantly, a problem to which we are coming. Furthermore, there is not much point in cleanup and organic renewal if the practices remain as at present, since it would amount to cleaning an Augean stable. Hence, the logical inference is to require the total internalization of all costs. This however would add still further to the pressure on the profits of individual firms. I do not see any plausible solution for this social dilemma within the framework of a 
capitalist world-economy, and hence I suggest that this is the second structural pressure on the accumulation of capital“ (Wallerstein 1999).

Entropy is a measure for the disorder of a system. llya Prigogine has shown that in the development of an open system (a system that exchanges matter and energy with ist environment) entropy decreases, i.e. order emerges from disorder (Nicolis/Prigogine 1989, Prigogine 1996):

$$
\frac{d S}{d t}<0, \frac{d S}{d t}=\frac{d_{i} S}{d t}+\frac{d_{e} S}{d t}, \mathrm{~d}_{\mathrm{e}} \mathrm{S} \text { is the entropy throughput of the system, } \mathrm{d}_{i} \mathrm{~S} \text { the entropy }
$$

All living systems are open systems, they import low-entropy energy that the use in order to produce order within the system and they export high-entropy energy. In the metabolism between society and nature the economy imports low-entropy energy from nature, uses this entropy in production in order to increase economic order (i.e. commodities are produced) and exports high-entropy energy in the forms of waste and emissions. The entropy within the economy decreases by increasing the entropy in the environment (for a discussion of the relationship of entropy, ecology, and economy cf. e.g. Beckenbach/Diefenbacher 1994, Altvater 1992, Burkett 2005). The ecosystems on earth import energy from sunlight and export lost heat, this process enables the recycling of matter. Whereas renewable resources (e.g. water, wind, tides, solar radiation, soil) are reproduced by nature due to the input of lowentropy sunlight, non-renewable resources such as petroleum, coal, metals, and natural gas form a factor that irreversibly diminishes by economic activity. Renewable resources in contrast to non-renewable ones can renew themselves at approximately the rate at which they are extracted by human activity, nonrenewable ones are irreversibly used up. An economy that is based on non-renewable resources increases the entropy of the natural environment, it produces waste and pollutants that can't be balanced by natural recycling. Hence there comes a point where quantity turns into quality and an ecological crisis emerges. Ecological crisis means that due to economic influences and export processes the entropy of the natural environment has increased to a point where ecosystems can't produce new order that balances the disorder generated by the human economy and where hence there's the threat that ecological processes and with them social systems break down.

The economy of the industrial society has since the $19^{\text {th }}$ century been based on fossil fuels and has already reached and crossed this crucial point. Elmar Altvater (1992) hence characterizes the capitalist economy as fossilistic production model. Entropy production has become a serious problem for modern society. The burning of fossil fuels in industry produces massive amounts of pollutants such as carbon dioxide that are emitted into air, soil, and water and due to their intensity can't be compensated by the entropy reduction of the recycling processes of the ecosystem of the earth. The capitalist economy aims at the accumulation of money capital, its criterion of efficiency is not the reduction of entropy production, but production of surplus value. With the accumulation of capital the entropy of the natural environment generally increases because capitalist production functions like a machine that devours ever more resources in order to disgorge ever more money capital. Its economically efficient to produce ecologically inefficiently, the natural global commons are increasingly used up and polluted by the processes of capital accumulation. The latter is only possible due to increasing inputs of energetic and natural resources. The economic expansiveness of the modern economy is at the root of ecological problems, capitalism treats nature as a tap and a sink.

Sustainable development requires the economy to be based on alternative energy forms such as solar energy, wind power, hydropower, geothermal power, and biomass energy (liquid biofuel, solid biomass, biogas). If a sustainable economy can be a capitalistic one is questionable because transforming the ecological foundation of society requires fundamental social changes. To revolutionize the technological system of society so that it is based on alternative energies and biotechnologies could in principle be 
organized within a capitalist economy, alternative energy and technologies would then become sources of profit. But such a development would require a fundamental transformation of technological systems that are mainly based on fossil energy and hence such a transition would seriously diminish profits and hence advance economic crises. Ecological sustainability hence is not compatible with economic rationality and interests. Late capitalism is a system where we find wars in which blood is shed for oil, the United States refuse to sign the Kyoto Protocol that would require them the reduce their collective emissions of greenhouse gases - carbon dioxide, methane, nitrous oxide, sulfur hexafluoride, HFCs, and PFCs - by $5.2 \%$ compared to the year 1990 because they argue that this agreement would impair the US economy. This gives us good reasons to assume that dominant political and economic interests see mechanisms that increase ecological sustainability as obstacles for capital accumulation. Hence an ecological sustainable capitalism (eco-capitalism) based on renewable resources, alternative technologies, and energy forms seems to be highly unlikely. Alternative energy forms and eco-technologies don't seem to be real options for the capitalist system because they are much less economically profitable than fossil and nuclear energy. Besides the problem of the limitation of natural resources it seems questionable that the capitalist production model that is based on mass production and mass consumption that enable capital accumulation could reduce the amount of waste generated by the superabundance of commodities without impairing economic profitability. Hence capitalistic economic rationality seems to antagonistically contradict ecological sustainability. A true alternative only seems to be the introduction of new technological systems based on renewable resources and energy forms and a solar revolution that requires a fundamental institutional change and an alternative economic and political model not oriented on exchange value and profit, i.e. a new society.

Some actors suggest that if natural resources were commodified and treated as economic resources the ecological crisis could be solved because individual property would be more carefully treated than a global natural commons that is considered by corporations as possibility for externalizing economic costs to society. Such arguments overlook that the root of the ecological crisis is the logic of accumulation that results in the depletion and pollution of natural resources and that the extension of property rights to nature doesn't challenge this root cause. Also models that consider the establishment of technologies that remove ecological pollution as possible solution of the ecological crisis are short-sighted because they again ignore the root causes of ecological degradation and that clean-up technologies require themselves energetic inputs and produce high-entropy outputs.

Whereas scholars like Hans Magnus Enzensberger (1996) and David Harvey (1996) ${ }^{2}$ have stressed that conservationism is a bourgeois ideology that stresses limits of growth in order to suggest small reforms of capitalism, forestall radical social change, and create new areas of capital accumulation in the form of an eco-industrial complex, John Bellamy Foster (2002) more realistically says that such discussions show "that infinite expansion within a fine environment [...] [is] a contradiction in terms. [...] Capitalist economies are geared first and foremost to the growth of profits, and hence to economic growth at virtually any cost - including the exploitation and the misery of the vast majority of the world's population. This rush to grow generally means rapid absorption of energy and materials and the dumping of more and more wastes into the environment - hence widening environmental degradation" (Bellamy Foster 2002: 10). Ecological degradation is not just an ideology, but a real global problem caused by capitalism and destructive industrial modes of production.

Nature and knowledge are both common products, they are not the result of singular production and labour processes: Natural resources are not produced by humans, but by nature itself. Knowledge is

\footnotetext{
${ }^{2}$ The "postulation of a planetary ecological crisis, the very idea that the planet is somehow 'vulnerable' to human action or that we can actually destroy the earth, repeats in negative form the hubristic claims of those who aspire to planetary domination. [...] Against this it is crucial to understand that it is materially impossible for us to destroy the planet earth, that the worst we can do is to engage in material transformations of our environment so as to make life less rather than more comfortable for our own species being“ (Harvey 1996: 194).
} 
produced not individually, but in co-operation, it has a historical and social character, i.e. new knowledge is based on and emerges from the whole prior existing knowledge. Hence one can't rationally argue that nature or knowledge are produced by one individual or company and that due to the private origin there should be a private ownership of it. The origin of nature and knowledge is fuzzy, hence they must be considered as common property that should be usable by all humans for free. This common character stems on the one hand from the natural character of material resources and on the other from the social and historical character of knowledge. Knowledge and nature enter the capitalist accumulation process as cheap or free resources. There is a tendency of the commodification of nature and knowledge in late capitalism; knowledge-based capitalism is characterized by an antagonism between common goods as open source and as private property. To be exact in the case of nature what is commodified is the access to nature and natural resources. Whereas new technologies enable people to co-operatively produce and freely share knowledge, corporations try to patent natural knowledge (e.g. genes, life-forms) and human knowledge (software patents, technology, digital products, etc.). The privatization of natural areas and resources and of public services is yet another aspect of the commodification of the commons. The struggles for reclaiming the commons constitute a central conflict of knowledge-based capitalism. The commodification and privatization of the commons can't be given reason for by arguing that they are privately produced, hence the legitimizations employed have to resort to irrational arguments.

Marx has stressed the character of nature as free product for capital and that science connects knowledge and nature in a form that allows appropriation of both resources by capital: "So also physical forces, like steam, water, etc., when appropriated to productive processes, cost nothing. [...] Once discovered, the law of the deviation of the magnetic needle in the field of an electric current, or the law of the magnetisation of iron, around which an electric current circulates, cost never a penny. But the exploitation of these laws for the purposes of telegraphy, etc., necessitates a costly and extensive apparatus. [...] Science, generally speaking, costs the capitalist nothing, a fact that by no means hinders him from exploiting it. The science of others is as much annexed by capital as the labour of others" (Marx 1867: 407). "Apart from the natural substances, it is possible to incorporate in the productive process natural forces, which do not cost anything, to act as agents with more or less heightened effect. The degree of their effectiveness depends on methods and scientific developments which cost the capitalist nothing" (Marx 1885: 357). "Natural elements entering as agents into production, and which cost nothing, no matter what role they play in production, do not enter as components of capital, but as a free gift of Nature to capital, that is, as a free gift of Nature's productive power to labour, which, however, appears as the productiveness of capital, as all other productivity under the capitalist mode of production" (Marx 1894: 753). The fetishistic character of capitalist production that makes social relationships appear like they are things (money, commodities) results in the fact that nature and labour appear to be the products of capital although capital is in fact their product: "Thus, not only does the historically developed social productiveness of labour, but also its natural productiveness, appear to be productiveness of the capital with which that labour is incorporated" (Marx 1867: 538).

Nature in the form of the means of production becomes part of the capitalist process, a means of producing surplus value, and hence becomes alien to labour because it is employed as a means of exploitation and extraction of surplus. Hence the human being in capitalism is not only estranged from production (because it doesn't own the products it produces), it is also estranged from nature that serves capitalist interests: Machinery "in itself it is a victory of man over the forces of Nature, but in the hands of capital, makes man the slave of those forces" (Marx 1867: 465)."The relation grows still more complicated and apparently more mysterious because, with the development of the specifically capitalist mode of production, it is not only these directly material things <all products of labour; considered as use-values, they are both material conditions of labour and products of labour; considered as exchange-values, they are materialised general labour-time or money> that get up on their hind legs to the labourer and confront him as "capital", but [also] the forms of socially developed labour - co-operation, manufacture (as a form of division of labour), the factory (as a form of social labour organised on machinery as its material basis) 
- all these appear as forms of the development of capital, and therefore the productive powers of labour built up on these forms of social labour consequently also science and the forces of nature - appear as productive powers of capital. In fact, the unity [of labour] in co-operation, the combination [of labour] through the division of labour, the use for productive purposes in machine industry of the forces of nature and science alongside the products of labour - all this confronts the individual labourers themselves as something extraneous and objective, as a mere form of existence of the means of labour that are independent of them and control them, just as the means of labour themselves [confront them,] in their simple visible form as materials, instruments, etc., as functions of capital and consequently of the capitalist. [...] But science realised in the machine appears as capital in relation to the labourers. And in fact all these applications of science, natural forces and products of labour on a large scale, these applications founded on social labour, themselves appear only as means for the exploitation of labour, as means of appropriating surplus-labour, and hence confront labour as powers belonging to capital. Capital naturally uses all these means only to exploit labour; but in order to exploit it, it must apply them in production. And so the development of the social productive powers of labour and the conditions for this development appear as acts of capital, towards which the individual labourer not only maintains a passive attitude, but which take place in opposition to him" (Marx 1862/63 (1): 366f).

Human knowledge organized in the form of science and human labour organized in the form of industry transforms nature into technologies, organs of human appropriation of nature: "Nature builds no machines, no locomotives, railways, electric telegraphs, self-acting mules etc. These are products of human industry; natural material transformed into organs of the human will over nature, or of human participation in nature. They are organs of the human brain, created by the human hand; the power of knowledge, objectified. The development of fixed capital indicates to what degree general social knowledge has become a direct force of production, and to what degree, hence, the conditions of the process of social life itself have come under the control of the general intellect and been transformed in accordance with it. To what degree the powers of social production have been produced, not only in the form of knowledge, but also as immediate organs of social practice, of the real life process" (Marx 1857/58: 602).

Marx has emphasized that nature as such has no value because it is not the product of human labour: "The waterfall, like land in general, and like any natural force, has no value because it does not represent any materialised labour, and therefore, it has no price, which is normally no more than the expression of value in money terms. Where there is no value, there is also eo ipso nothing to be expressed in money. This price is nothing more than the capitalised rent" (Marx 1894: 660f). Against Say an McCulloch Marx argued that natural forces don't produce value: "I can have as much air, water, etc., as I like. But I possess them as productive agents only if I have the commodities, the things, by the use of which these agents will operate as such" (Marx 1862/63 (3): 182).

\section{4. Marxism and Ecology}

Many Greens are sceptical towards Marxism because they associate with it Stalinism's and neoStalinism's economic practices that have caused severe environmental degradation in Eastern Europe, a productivist and technocratic logic that considers nature as a mere resource that can be limitlessly exploited in order to increase productivity, and an outdated concept of class struggle that doesn't seem to explain ecological struggles and concerns (Soper 1996). The view of Leninism and Stalinism on nature and technology was that capitalist technology should be adopted and imitated in order to increase productivity in "Socialist" society. Hence there was no qualitative transformation of the productive forces, the latter were developed in unsustainable ways that had destructive effects on both nature and society. E.g. Lenin was impressed by the inhumane Taylor system and didn't realize that a new society also needs to humanize technology and its relationship to nature. "The Taylor system, the last word of capitalism in this respect, like all capitalist progress, is a combination of the refined brutality of bourgeois exploitation 
and a number of the greatest scientific achievements in the field of analysing mechanical motions during work, the elimination of superfluous and awkward motions, the elaboration of correct methods of work, the introduction of the best system of accounting and control, etc. The Soviet Republic must at all costs adopt all that is valuable in the achievements of science and technology in this field. The possibility of building socialism depends exactly upon our success in combining the Soviet power and the Soviet organisation of administration with the up-to-date achievements of capitalism. We must organise in Russia the study and teaching of the Taylor system and systematically try it out and adapt it to our own ends" (Lenin 1918). Similar to Lenin Antonio Gramsci (1934) evaluated the Taylor system very positively and argued that it would have a socialist potential. Arran Gare (1996) has stressed that in the early Soviet Union there have been environmentalist approaches (Bogdanov, the Proletkul't movement, Abram Moiseyevich Deborin, Daniil Nikolaevich Kashkarov, Vladimir Vladimirovich Stanchinskii) that have been repelled by the rise of Stalinism and its productivist ideology.

Alain Lipietz (2000) argues that the red and the green model are similar in that they are both "progressive, materialist (starting from a critical knowledge of the real), dialectical (assuming that this reality will engender its own material critique); and historical ('now is the time!')". But they would be totally different in respect to their ideas on the productive forces: the "idea that an 'advance of the productive forces' drives other forms of progress is totally absent from the green paradigm. [...] Its vision of history is not a tale of progress. [...] The historical and dialectical materialism of the greens is non-teleological, then, even rather pessimistic". Reds would evaluate the productive forces positively, greens negatively.

It is true that especially in the later writings of Marx and Engels one can find formulations that suggest a productivist logic that sees nature as an enemy opposed to man, as a resource and object that must be mastered, exploited, and controlled. There surely is a lack of ecological consciousness in such passages, but in my view one nonetheless can't blame Marx and Engels for the ecological disasters in the Soviet Union.

Here are some examples of this tendency: Marx writes that man "opposes himself to Nature as one of her own forces" (Marx 1867: 192). "It is the necessity of bringing a natural force under the control of society, of economising, of appropriating or subduing it on a large scale by the work of man's hand, that first plays the decisive part in the history of industry" (Marx 1867: 537). Industrialism shows that "huge natural forces can be pressed into the service of production" (Marx 1867: 652). The improvement of machines would result in "a more advantageous exploitation of the forces of nature on a larger scale" (Marx 1849: 417). In Communism man would be the lord of nature: "The whole sphere of the conditions of life which environ man, and which have hitherto ruled man, now comes under the dominion and control of man, who for the first time becomes the real, conscious lord of nature, because he has now become master of his own social organization" (Engels 1880: 226). Capitalism would subject nature's forces: "The bourgeoisie, during its rule of scarce one hundred years, has created more massive and more colossal productive forces than have all preceding generations together. Subjection of Nature's forces to man, machinery, application of chemistry to industry and agriculture, steam-navigation, railways, electric telegraphs, clearing of whole continents for cultivation, canalisation or rivers, whole populations conjured out of the ground - what earlier century had even a presentiment that such productive forces slumbered in the lap of social labour?" (Marx/Engels 1848: 467).

Whereas in the early writings of Marx there was the tendency to assume that in communism man and society come closer to each other, in later writings there is the tendency to stress difference, the opposition between nature and society, i.e. the necessity of man to "wrestle with nature" in all societal formations in order to survive: "The actual wealth of society, and the possibility of constantly expanding its reproduction process, therefore, do not depend upon the duration of surplus-labour, but upon its productivity and the more or less copious conditions of production under which it is performed. In fact, the realm of freedom actually begins only where labour which is determined by necessity and mundane 
considerations ceases; thus in the very nature of things it lies beyond the sphere of actual material production. Just as the savage must wrestle with Nature to satisfy his wants, to maintain and reproduce life, so must civilised man, and he must do so in all social formations and under all possible modes of production. With his development this realm of physical necessity expands as a result of his wants; but, at the same time, the forces of production which satisfy these wants also increase. Freedom in this field can only consist in socialised man, the associated producers, rationally regulating their interchange with Nature, bringing it under their common control, instead of being ruled by it as by the blind forces of Nature; and achieving this with the least expenditure of energy and under conditions most favourable to, and worthy of, their human nature. But it nonetheless still remains a realm of necessity. Beyond it begins that development of human energy which is an end in itself, the true realm of freedom, which, however, can blossom forth only with this realm of necessity as its basis. The shortening of the working-day is its basic prerequisite" (Marx 1894: 828). But one should also note that in this passage Marx stresses that in communism man rationally regulates his interchange with nature. This implies: 1 . That the man-naturerelationship has been irrationally organized in modern society; 2 .That nature should be appropriated in sustainable ways because ecological degradation that destroys the fundamental living conditions of human beings can hardly be considered as being part of a humane rationality.

Throughout the works of Marx and Engels, starting in such early writings such as the "EconomicPhilosophical Manuscripts" (1844), "The Conditions of the Working Class in England" (1845)", and "The German Ideology" (1846), one can find many passages that show that they thought that capitalism and modern industrial production have ecologically unsustainable effects and that capitalism means not only social alienation of the majority of the people, but also an alienation from nature because the latter would in the form of technology become a means of exploitation. Hence Marx and Engels seem to suggest an antagonism between nature and society in modern society and believe that in a free society there must also be an alternative relationship between society and nature. This latter idea can be found in formulations that suggest that Communism means the humanization of nature, the naturalization of society, and the resurrection of nature. Such passages reflect the idea that in Communism nature could be used by man in a way that allows the minimization of necessary labour and the maximization of free time and self-determined activity. This would be the essence of a true humanism. That in such a society there could be a changed relationship to nature that recognizes nature as the foundation of society and establishes a certain unity in difference seems to suggest that Marx and Engels were well aware of the need to protect nature and to appropriate it in sustainable ways and that Communism can be considered as the sublation of the antagonism between nature and society. I will try to show that Marx and Engels can indeed be considered as precursors of environmentalism and that hence although it makes sense to criticize the determinist logic of Stalinism, it doesn't make sense to argue that Marx and Engels believed in the necessity of man's destructive relationship towards nature and that rather one should try to reconcile Marxist and Green thinking. It is one of Historical Materialism's fundamental insights that ideas have a historical character and depend on the dominant social forms. That Marx and Engels had ecological concerns shows that they were ahead of their time, that they didn't give central importance to them is due to the fact that in $19^{\text {th }}$ century capitalism caused acute social problems, but not a global ecological crisis.

I think that Alain Lipietz (2000) is wrong in arguing that "Marx shares entirely the Biblio-Cartesian ideology of the conquest of nature, as would be taken to its extreme, first, by the 'conquering bourgeois,' and then by the sorceror's apprentices of Stalinist Siberia and the Khazakstan steppes. [...] I am very much afraid that, for Marx himself, Mother-Nature was taken into account only to be subordinated to the productivist rule of Father-Work". Such an assumption is based on a selective reading of Marx. I will now try to show that this tendency in Marx's writings has been challenged by one of ecological consciousness. Formulations of Marx like the one that nature is the inorganic body of man make Lipietz feel uneasy because "better again is he who loves the other living species as his own. Only perfect is he who 
recognizes in his own body the inorganic body of nature". This formulation sounds like one of deep ecology that insists on the identity of nature and man without seeing the difference.

Both Marx and Engels described the living conditions of the industrial labour force as inhumane and pointed towards the destruction of the ecosphere as part of these conditions. Engels says about industrial labour: "And a sentence to such work, to work which takes his whole time for itself, leaving him scarcely time to eat and sleep, none for physical exercise in the open air, or the enjoyment of Nature, much less for mental activity, how can such a sentence help degrading a human being to the level of a brute?" (Engels 1845: 347). Here is his description of Little Ireland, an area in Manchester: "But the most horrible spot (if I should describe all the separate spots in detail I should never come to the end) lies on the Manchester side, immediately south-west of Oxford Road, and is known as Little Ireland. [...] The cottages are old, dirty, and of the smallest sort, the streets uneven, fallen into ruts and in part without drains or pavement; masses of refuse, offal and sickening filth lie among standing pools in all directions; the atmosphere is poisoned by the effluvia from these, and laden and darkened by the smoke of a dozen tall factory chimneys. A horde of ragged women and children swarm about here, as filthy as the swine that thrive upon the garbage heaps and in the puddles. In short, the whole rookery furnishes such a hateful and repulsive spectacle as can hardly be equalled in the worst court on the Irk" (Engels 1845: 292).

Similar passages can be found in the works of Marx: "Even the need for fresh air ceases to be a need for the worker [in capitalism]. Man returns to a cave dwelling, which is now, however, contaminated with the pestilential breath of civilisation, and which he continues to occupy only precariously, it being for him an alien habitation which can be withdrawn from him any day - a place from which, if he does not pay, he can be thrown out any day. [...] Light, air, etc. - the simplest animal cleanliness - ceases to be a need for man. Filth, this stagnation and putrefaction of man - the sewage of civilisation (speaking quite literally) comes to be the element of life - for him. Utter, unnatural depravation, putrefied nature, comes to be his life-element." (Marx 1844: 548). "The way in which nature is perceived under the law of private property is one of utter scorn, a debasement of nature, in effect" (Marx 1843: 375).

In Marx's and Engels' thinking one can find the idea that in capitalism the productive forces become destructive forces, they take on qualities that damage society: "In the development of productive forces there comes a stage when productive forces and means of intercourse are brought into being, which, under the existing relationships, only cause mischief, and are no longer productive but destructive forces (machinery and money); and connected with this a class is called forth, which has to bear all the burdens of society without enjoying its advantages, which, ousted from society, is forced into the most decided antagonism to all other classes; a class which forms the majority of all members of society, and from which emanates the consciousness of the necessity of a fundamental revolution, the communist consciousness, which may, of course, arise among the other classes too through the contemplation of the situation of this class" (Marx/Engels 1846: 69). This passage from the "German Ideolgoy" seems to suggest that the productive forces are socially destructive in modern society; they cause social problems such as poverty, precarious living conditions, and unemployment. As the following quotations will show for Marx and Engels this destructive quality of the modern productive forces also includes negative effects on nature, hence these forces are both socially and ecologically destructive, society is damaged by modern technology in both a social and an ecological respect.

For Marx the destructive power of capital also turns against nature: "It [Capital] is destructive towards all of this, and constantly revolutionizes it, tearing down all the barriers which hem in the development of the forces of production, the expansion of needs, the all-sided development of production, and the exploitation and exchange of natural and mental forces" (Marx 1857/58: 323). Engels argues that the human mastery of nature can have unforeseen effects: "Let us not, however, flatter ourselves overmuch on account of our human victories over nature. For each such victory nature takes its revenge on us. Each 
victory, it is true, in the first place brings about the results we expected, but in the second and third places it has quite different, unforeseen effects which only too often cancel the first" (Engels 1886: 452ff).

Marx has pointed out that capitalism destroys both nature and the labourer, it hence can be considered as ecologically and socially destructive: "Capitalist production, by collecting the population in great centres, and causing an ever-increasing preponderance of town population, on the one hand concentrates the historical motive power of society; on the other hand, it disturbs the circulation of matter between man and the soil, i.e., prevents the return to the soil of its elements consumed by man in the form of food and clothing; it therefore violates the conditions necessary to lasting fertility of the soil. By this action it destroys at the same time the health of the town labourer and the intellectual life of the rural labourer. But while upsetting the naturally grown conditions for the maintenance of that circulation of matter, it imperiously calls for its restoration as a system, as a regulating law of social production, and under a form appropriate to the full development of the human race. [...] In modern agriculture, as in the urban industries, the increased productiveness and quantity of the labour set in motion are bought at the cost of laying waste and consuming by disease labour-power itself. Moreover, all progress in capitalistic agriculture is a progress in the art, not only of robbing the labourer, but of robbing the soil; all progress in increasing the fertility of the soil for a given time, is a progress towards ruining the lasting sources of that fertility. The more a country starts its development on the foundation of modern industry, like the United States, for example, the more rapid is this process of destruction. Capitalist production, therefore, develops technology, and the combining together of various processes into a social whole, only by sapping the original sources of all wealth - the soil and the labourer" (Marx 1867: 529f).

The productive forces have by modern industrialism been developed in ways that have increased productivity at the cost of damaging society and nature, hence productivism has not only caused social destruction (poverty, unemployment, etc.), but also ecological destruction. The productive forces are in modern society socially and ecologically destructive forces. Hans Magnus Enzensberger has argued that due to the ecological problems "it seems completely absurd to speak in a short-term perspective, as Marcuse has done, of a 'society of superabundance' or of the abolition of want. [...] any possible freedom and $[\ldots]$ every political theory and practice $[\ldots]$ is confronted not with the problem of abundance, but with that of survival. [...] Socialism, which was once a promise of liberation, has become a question of survival" (Enzensberger 1996: 39, 48). For Marcuse a free society is a high-technology society that makes use of its productivity to abolish drudgery, maximize free time, and minimize necessary labour time. "Consequently, if men no longer had to spend their lives in the realm of necessity, truth and a true human existence would be in a strict and real sense universal. [...] truth presupposes freedom from toil" (Marcuse 1964: 129). He argues that modern technology both is a destructive force and at the same time has created the foundations for a free society, hence one would have to make use of the creative potential of technology and get rid of its destructive qualities which would imply to redesign technology. If freedom were only about survival, a free society would be one that guarantees survival of humankind. But survival could still be based on hard labour, exploitation, or slavery. Hence survival is not the characteristic aspect of freedom, a free society must both guarantee survival and well-being of all its human inhabitants. What Marcuse hence is arguing for is an alternative technology that both makes possible a sustainable appropriation of nature and a high productivity that minimizes necessary labour and creates a realm of freedom (from necessity). Socialism is both a question of survival and liberation, there is no liberation without survival, and probably no survival without liberation.

Communism is not just a socialization of the ownership of the means of production, it implies revolutions of all relationships of society, social relationships and relationships between humans and things. A truly Communist society is a form of society that provides human well-being, a good life, and wealth for all, hence it implies social and ecological sustainability, i.e. it eradicates poverty and hard labour and treats nature in ways so that the latter can continuously exist undamaged as the very source of 
prosperity of society. The idea of an alternative society-nature-relationship and of nature conservation in Communism can already be found in the works of Marx and Engels. The transition towards Communism is not only a sublation of economic and political antagonism (such as the ones between productive forces and relations of production, between inclusion and exclusion, and between the rulers and the ruled), but also a sublation of the antagonism between nature and society. This doesn't mean a return to nature where man is closer to nature, but a non-destructive appropriation of nature that allows both society and nature to blossom. Society and nature hence will remain different, but the higher-order-identity that connects them will be a non-destructive, sustainable one.

Engels stresses that man shouldn't treat nature like an emperor who exploits human beings: "We by no means rule over nature like a conqueror over a foreign people, like someone standing outside nature - but that we, with flesh, blood and brain, belong to nature, and exist in its midst, and that all our mastery of it consists in the fact that we have the advantage over all other creatures of being able to learn its laws and apply them correctly" (Engels 1886: 453).

Marx points out that in Communism the antagonism between nature and society can be sublated. This suggest not only an appropriation of the forces of nature that allows the minimization of necessary labour time and realizes a realm of freedom, but also to treat nature in a non-destructive way. "This communism, as fully developed naturalism, equals humanism, and as fully developed humanism equals naturalism; it is the genuine resolution of the conflict between man and nature and between man and man - the true resolution of the strife between existence and essence, between objectification and self-confirmation, between freedom and necessity, between the individual and the species. Communism is the riddle of history solved, and it knows itself to be this solution. [...] [In Communism] society is the complete unity of man with nature - the true resurrection of nature - the consistent naturalism of man and the consistent humanism of nature " (Marx 1844: 536, 538).

Even an anticipation of the idea of sustainable development can be found in Marx's writings. He argues that in communism the globe must be improved by human beings and passed on to succeeding generations in such a condition. "From the standpoint of a higher economic form of society, private ownership of the globe by single individuals will appear quite as absurd as private ownership of one man by another. Even a whole society, a nation, or even all simultaneously existing societies taken together, are not the owners of the globe. They are only its possessors, its usufructuaries, and, like boni patres familias, they must hand it down to succeeding generations in an improved condition" (Marx 1894: 784).If one compares this passage to the most common definition of sustainable development by the Brundtland Commission - "Sustainable development is development that meets the needs of the present without compromising the ability of future generations to meet their own needs" (WCED 1987: 43) - one finds a striking concurrence.

The question whether Marx and Engels were blind for ecological devastation and have argued in favour of ecological degradation in order to advance human ends can be answered negatively. Taken together I believe there is much evidence that Marx and Engels can indeed be considered as "precursors of human ecology" (Vaillancourt 1996: 56). Unfortunately for a long time Marxism only scarcely realized the ecological potential of Marx's and Engels' thinking.

The socially and ecologically destructive effects of both capitalism and the Soviet system are an indication that the principles of domination and heteronomy in any form cause great problems and result in barbarism. Social Anarchism has for a long time better understood than Marxism that critical thinking must not only be a critique of capitalism, but a general critique of domination and that ecological and social problems are not simply ruled out by the socialization of the means of production, but require a fundamental reorganization of society as a whole and of all its subsystems. During the last three decades Marxism has increasingly become more aware of ecological problems, the non-economic aspects of many 
social problems, and the necessity of a critique of the productive forces as the works of Marxists such as Herbert Marcuse, Ernst Bloch, Alain Lipietz, John Bellamy Foster, Steven Vogel, James O'Connor, Ted Benton, and André Gorz show. Critical, unorthodox Marxism increasingly converges with the ideas of Social Anarchist thinkers such as Peter Kropotkin, Murray Bookchin, Alexander Berkman, Erich Mühsam, Rudolph Rocker, Daniel Guérin, and others.

Murray Bookchin's Social Ecology/Dialectical Naturalism considers ecological problems as social problems that stem from social relationships of domination. "The way we view or position in the natural world is deeply entangled with the way we organize the social world. In large part, the former derives from the latter and serves, in turn, to reinforce social ideology. Every society projects its own perception of itself onto nature" (Bookchin 1995: 86). "What literally defines social ecology as "social" is its recognition of the often overlooked fact that nearly all our present ecological problems arise from deep-seated social problems. Conversely, present ecological problems cannot be clearly understood, much less resolved, without resolutely dealing with problems within society. To make this point more concrete: economic, ethnic, cultural, and gender conflicts, among many others, lie at the core of the most serious ecological dislocations we face today--apart, to be sure, from those that are produced by natural catastrophes" (Bookchin 1993). The notion of "dominating nature stems from the domination of human by human. [...] I argue that the idea of dominating nature first arose within society as part of its institutionalisation into gerontocraties that placed the young in varying degrees of servitude to the old and in patriarchies that placed women in varying degrees of servitude to men - not in any endeavour to 'control' nature or natural forces. [...] Hence, domination can be definitely removed only by resolving problematics that have their origins in hierarchy and status, not in class and the technological control of nature alone" (Bookchin 1995: 142).

Bookchin revives the insight of Peter Kropotkin's Communist Anarchism that nature and society are based on mutualism and co-operation ${ }^{3}$ and that hence a co-operative society based on mutual aid, participation, and grass roots democracy in all its realms would be the actualization of potentials that are immanent in nature and society. A creative metabolism between humanity and nature would have to be based on a society that is based on sharing, co-operation, and direct democracy. A social and ecologically sustainable society would have to be a self-managed, communalistic society based on co-operating decentralized direct democratic communes - a "commune of the communes" (Bookchin 1994).

Bookchin's form of dialectic thinking argues that there is directionality toward ever-greater differentiation in the world that opens up ever new potentialities and that all Being is Becoming. "Dialectical naturalism [...] conceives finiteness and contradiction as distinctly natural in the sense that things and phenomena are incomplete and unactualized in their development - not 'imperfect' in any idealistic or supranatural sense. Until they have been constituted to become, they exist in a dynamic tension" (Bookchin 1995: 19f). Bookchin distinguishes his concept of development from the one of mysticism/eco-spiritualism and orthodox Marxism that are all based on reductionism and mechanic determinism, an absorption of society by nature in the case of eco-spiritualism and an absorption of nature by society in the case of orthodox Marxism. He revives the concept of truth immanent in the early writings of Marx and the works of Marcuse by arguing that a good society is one that has fulfilled and actualized its potentialities. Dialectical development would continuously produce levels of organization that have new qualities. Coming close to ideas of a dialectical theory of self-organization he considers matter as dynamic, active, and selforganizing: "The universe bears witness to a developing - not merely moving - substance, whose most

\footnotetext{
3 "As soon as we study animals - not in laboratories and museums only, but in the forest and the prairie, in the steppe and the mountains - we at once perceive that though there is an immense amount of warfare and extermination going on amidst various species, and especially amidst various classes of animals, there is, at the same time, as much, or perhaps even more, of mutual support, mutual aid, and mutual defence amidst animals belonging to the same species or, at least, to the same society. Sociability is as much a law of nature as mutual struggle." (Kropotkin 1914: 26).
} 
dynamic and creative attribute is its unceasing capacity for self-organization into increasingly complex forms. [...] Recent data support the applicability of Peter Kropotkin's mutualistic naturalism not only to relationships between species but among complex cellular forms. [...] The prospect that life and all its attributes are latent in matter as such, that biological evolution is deeply rooted in symbiosis or mutualism, suggests that what we call matter is actually active substance" (Bookchin 1995: 59-61). "We require a way of thinking that recognizes that 'what-is' as it seems to lie before our eyes is always developing into 'whatit-is-not,' that it is engaged in a continual self-organizing process in which past and present, seen as a richly differentiated but shared continuum, give rise to a new potentiality for a future, ever-richer degree of wholeness" (Bookchin 1993).

Society would be one of the levels produced by the self-organization of nature, it would be based on first nature, but would be a distinct second nature. The central idea of Social Ecology for Bookchin is that first nature gave rise to a second nature (society) that affects and coins first nature. Respect for nature would not arise from values or rights that are immanent in nature, but from the ability of humans would have the ability to consider nature as valuable and important for society. Liberation would be the transcendence of both first nature and second nature into a new domain of a "free nature" that would wilfully and thinkingly cope with conflict, contingency, waste, and compulsion (Bookchin 1995: 136). "Second nature, far from marking the fulfilment of human potentialities, is riddled by contradictions, antagonisms, and conflicting interests that have distorted humanity's unique capacities for development. It contains both the danger of tearing down the biosphere and, given a further development of humanity toward an ecological society, the capacity to provide an entirely new ecological dispensation" (Bookchin 1993).

Community would be a "desideratum in nature and society" (Bookchin 1995: 64). "Mutalism, freedom, and subjectivity are not solely human values or concerns. They appear, however germinally, in larger cosmic or organic processes, but they require no Aristotelian God to motivate them, no Hegelian Spirit to vitalize them. If social ecology can provide a coherent focus on the unity of mutualism, freedom, and subjectivity as aspects of a cooperative society that is free of domination and guided by the reflection an reason, it will have removed the difficulties that have plagued naturalistic ethics for so long" (Bookchin 1995: 65f). Symbiosis and participation would factor in the evolution of species (Bookchin 1995: 78). Bookchin stresses that community is an aspect of evolution and human beings are actively participating agents in their own evolution. A fully co-operative and participatory society would be the actualization of latent human potentiality and hence also of a latent potentiality that nature has produced in its development process. A co-operative, participatory, ecological society would be "the fulfilment of a major tendency in natural evolution" (Bookchin 1995: 140). Freedom would be "the unfolding of human potentialities for freedom, self-consciousness, and cooperation" (Bookchin 1995: 159). Bookchin considers humans as active agents that may or may not elaborate their potentialities in social evolution (Bookchin 1995: 168). An ecological dialectic would open the way to an ethics that is rooted in the objectivity of the potential (Bookchin 1995: 131). Social ecology "advances an ethics of complementarity in which human beings must play a supportive role in perpetuating the integrity of the biosphere, as potentially, at least, the most conscious products of natural evolution" (Bookchin 1993).

There is a certain danger of anthropomorphism in saying that co-operation and participation are inherent in nature, but Bookchin is well aware that social participation and co-operation are based on selfconscious activity that can make choices between different alternatives and can't be found in nonhuman nature. I would exercise more carefulness in employing the notions of co-operation and participation and would avoid speaking of an unfolding of potentialities in order to stress that social potentialities are not pre-existing in nature, but are produced by human beings in society. But the important idea in Bookchin's thinking for me is that all world processes are based on dynamic interaction processes that act synergetically and produce new qualities of Being. The self-organization of matter is an active, networked, synergetic, productive process. Acknowledging this fact helps us in arguing that human co-operation is the 
specific societal form of synergetical interaction and that a fully co-operative society is one that actualizes the essential potentials of society to a full extent and that hence such a society is a true society (Fuchs 2003a). Self-organization theory shows that interaction is a central feature of nature and society and hence I find it important to elaborate the critical potentials of this theory for society that can help criticizing the fetishism of modern society that naturalizes competition as "human nature". Malthus, Spencer, Darwin and the followers of Darwin were socialized in a competitive capitalist environment, their thinking was biased by positively assessing competition.

There is a certain unconscious, spontaneous germ form of co-operation in nature that I would term interaction. In order to stress the self-conscious, creative, anticipatory, active specificity of the human social world I would other than Bookchin reserve the term co-operation strictly for the human realm where it designates social relationships where human actors work creatively together, produce a new emergent reality, have shared goals, all benefit from co-operating, can reach their goals in joint effort more quickly and more efficiently than on an individual basis, make concerted use of existing structures in order to produce new structures, learn from each other mutually, are interconnected in a social network, and are mutually dependent and responsible (Fuchs 2003a). Co-operation is a more fundamental social principle than competition, the domination of society by the latter has produced a situation where the further existence of humanity is at high risk. Co-operation and participation can work as evolutionary guidance principles that enable a conscious evolution that increases the possibility that we will not face ultimate destruction and that we will advance towards an inclusive, integrative society that is based on the principle of self-organization in all social areas and enables a socially and ecologically sustainable development of society.

\section{II.5. Nature as a Subject and the Foundations of Ecological Marxism}

Marx wrote in the Preface to Capital that there are "natural laws of capitalist production", "tendencies working with iron necessity towards inevitable results" (Marx 1867: 12) and that "capitalist production begets, with the inexorability of a law of Nature, its own negation" (Marx 1867: 791). Alfred Schmidt (1971) has argued that this shouldn't be viewed as a deterministic conception of societal development that transfers natural laws to the social realm, but that Marx wanted to express by these formulations that alienated social structures that are not controlled by individuals dominate the human being in capitalism. The following passage seems to substantiate this view: "My standpoint, from which the evolution of the economic formation of society is viewed as a process of natural history, can less than any other make the individual responsible for relations whose creature he socially remains, however much he may subjectively raise himself above them" (Marx 1867: 16).

Stalin (1938) misinterpreted Marx and argued that dialectics apply similarly to nature and society and cause a linear, successive development in both realms. Stalin overlooks that social dialectics differ from natural dialectics in the respect that human beings have a much greater degree of freedom of choice than nature does have, they can make a conscious difference that makes a difference in society. Stalin's interpretation of dialectics is structural, functionalistic, and deterministic. Based on the deterministic naturalization of society he argues that "revolutions made by oppressed classes are a quite natural and inevitable phenomenon" and based on this mechanic determinism he says that "the U.S.S.R. has already done away with capitalism and has set up a socialist system" where "the social ownership of the means of production fully corresponds to the social character of the process of production", "the productive forces [...] develop at an accelerated pace; for the relations of production that correspond to them offer full scope for such development", and where "there are no longer exploiters and exploited". Stalin interprets the dialectical movement of society as a natural law in order to idealize the Soviet system that was indeed a system of terror, domination, exploitation, and repression and argues that this system must be considered as a free society because it would be the system following capitalism and according to historical laws and 
the natural development of society a free society would follow capitalism. In Stalinism (and similarly in Maoism) Dialectics became an ideology.

Instead of a deterministic interpretation of the Marxian Dialectic, one that emphasizes human practice seems to be more appropriate. Such an interpretation has e.g. been provided by Herbert Marcuse who has argued that in Marx's dialectic capitalism is an antagonistic system that negates human interests and that a truly human society can only be established by a negation of the negation that is the historical practice of the human being. "It would be a distortion of the entire significance of Marxian theory to argue from the inexorable necessity that governs the development of capitalism to a similar necessity in the matter of transformation to socialism. When capitalism is negated, social processes no longer stand under the rule of blind natural laws. This is precisely what distinguishes the nature of the new from the old. The transition from capitalism's inevitable death to socialism is necessary, but only in the sense that the full development of the individual is necessary. The new social union of individuals, again, is necessary, but only in the sense that it is necessary to use available productive forces for the general satisfaction of all individuals. It is the realization of freedom and happiness that necessitates the establishment of an order wherein associated individuals will determine the organization of their life. We have already emphasized that the qualities of the future society are reflected in the current forces that are driving towards its realization. There can be no blind necessity in tendencies that terminate in a free and self-conscious society. The negation of capitalism begins within capitalism itself, but even in the phases that precede revolution there is active the rational spontaneity that will animate the post-revolutionary phases. The revolution depends indeed upon a totality of objective conditions: it requires a certain attained level of material and intellectual culture, a self-conscious and organized working class on an international scale, acute class struggle. These become revolutionary conditions, however, only if seized upon and directed by a conscious activity that has in mind the socialist goal. Not the slightest natural necessity or automatic inevitability guarantees the transition from capitalism to socialism. [...] The realization of freedom and reason requires the free rationality of those who achieve it. Marxian theory is, then, incompatible with fatalistic determinism“ (Marcuse 1999: 317-319).

A mechanic dialectic can be avoided by an emphasis on practice and subjectivity that argues that the objective dialectic sets conditions, i.e. enables and constrains the subjective dialectic of human practice that can based on conditioning structures produce different historical alternatives of development.

Avoiding deterministic assumptions and linearism means not only to question the assumption that there is an automatic historical progress in the development of the productive forces, it also means to criticize the hypothesis that modern history must mean automatic historical regression. The modern mastery of nature has not only increased productivity and the total wealth of society, it also has had negative feedback on society where it has produced social and ecological catastrophes. The attempt to control nature has gone out of control, the control of nature by technologies has in the end been unsuccessful, the outcome is that nature has uncontrollable negative effects on society. Enlightenment reason turns against itself and against its own notions such as freedom, justice, and truth. Enlightenment reason wanted to master nature, but nature returns in the form of ecological destruction and the ideological naturalization of domination in the form of fetishism (of commodities, race, nation, gender, etc.). "With the spread of the bourgeois commodity economy the dark horizon of myth is illuminated by the sun of calculating reason, beneath whose icy rays the seeds of the new barbarism are germinating. Under the compulsion of power, human labor has always led away from myth and, under power, has always fallen back under its spell" (Horkheimer/Adorno 2002: 25). Otherwise than Orthodox Marxism that assumed an automatic progress in the mastery of nature by technology that would ultimately result in Communism, Horkheimer and Adorno assumed an automatic regression in the mastery of nature by technology that results in a series of catastrophes. In Orthodox Marxism (such as Stalinism or Maoism) man's activity in nature appears as purely positive and is associated with liberation, Horkheimer and Adorno see such activity as purely negative and associate it with domination. Both attempts are deterministic and linear, they don't see the 
dialectical character of modern technologies that pits forward antagonistic social tendencies, opportunities and risks at the same time. Human practice can appropriate nature in both sustainable and unsustainable ways, there is no pre-determined development of the nature-society-relationship.

I want to show now that in order to incorporate ecological thinking into a Marxist approach, stressing subjectivity in society should not only include the conscious activity of human beings, but should also acknowledge nature as a producing subject.

For Alfred Schmidt Engels' dialectics of nature are "dogmatic metaphysics" (Schmidt 1971: 46). Herbert Marcuse (1958) has argued that nature "seems to lie outside the realm of dialectic" (Marcuse 1958: 144), that Stalinism based on Engels' dialectics of nature has argued that there are supra-historical laws that determine society and that this has resulted in a mechanic determinism that justifies the dictatorship of the Soviet Communist party over the people. "[In Soviet ideology] the consciousness and action of the proletariat then are largely determined by the 'blind laws' of the capitalist process instead of having broken through this determinism. Consequently, the party, or rather the party leadership, appears as the historical repository of the 'true' interests of the proletariat, working by dictum and decree, and the proletariat becomes the object of these decisions. [...] the capitalist development, the transition to socialism, and the subsequent development of Soviet society through its various phases is presented as the unfolding of a system of objective forces that could not have unfolded otherwise. To be sure, strong and constant emphasis is placed on the guiding role of the Communist Party and its leaders [...] The subjective factor no longer appears as an integral element and stage of the objective dialectic" (Marcuse 1958: 147ff). The idea of a dialectic of nature would serve as the ideological stabilization of the totalitarian Soviet state. The first Marxist who argued that Engels' dialectics of nature was a misconception was Georg Lukács who said that only society is dialectical: "The misunderstandings that arise from Engels' account of dialectics can in the main be put down to the fact that Engels - following Hegel's mistaken lead - extended the method to apply also to nature. However, the crucial determinants of dialectics - the interaction of subject and object, the unity of theory and practice, the historical changes in the reality underlying the categories as the root cause of changes in thought, etc. - are absent from our knowledge of nature" (Lukács 1971: 24). For Lukács nature is strictly a social category.

But there is a tendency in Marcuse's thinking that runs counter to the tendency of considering nature as not being dialectical, Marcuse influenced by the rise of the ecology movement in his late writings considered nature as a subject: "Commercialized nature, polluted nature, militarized nature cut down the life environment of man, not only in an ecological but also in a very existential sense. It blocks the erotic cathexis (and transformation) of his environment: it deprives man from finding himself in nature, beyond and this side of alienation; it also prevents him from recognizing nature as subject in its own right - a subject with which to live in a common human universe" (Marcuse 1972: 60). In a free society nature "would appear not merely as stuff - organic or inorganic matter - but as life force in its own right, as subject-object; the striving for life is the substance common to man and nature. Man would then form a living object" (ibid.: 65). Although Marcuse has argued that dialectical reasoning doesn't apply to nature as such, he sees nature as a producing subject. But if nature is active and changes itself, this implies a dynamic and hence dialectical character. When Marcuse argues that "liberation of nature is the recovery of the life-enhancing forces in nature" (ibid.: 60), there is an "erotic energy of nature - an energy which is there to be liberated; nature, too, awaits the revolution!" (ibid.: 74), and that a free society would be "oriented on the life-enhancing, sensuous, aesthetic qualities inherent in nature" (ibid.: 67), he doesn't want to express like Deep Ecology that nature is animistic, spiritual and has inherent values, rather he wants to stress that nature is a material potentiality that in a free society can be creatively instead of destructively used by human beings in order to abolish toil and maximize free time and that a free society will be a society of a more free play of human drives, the inner sexual nature of human beings. 
Also Ernst Bloch considers nature as a subject, for him nature is materially open (Bloch 1959: 237), being-in-possibility/dynamei on (ibid.: 238, 271f), potentiality (ibid.: 238), the correlate of the objectively real possible (Bloch 1963/64: 233, Bloch 1959: 271-278), a process (Bloch 1959: 239, Bloch 1963/64: $203,207,209$ ), based on the transformation of the world out of itself (self-transformation, Bloch 1959: 310, 358), matter that moves and forms itself (Bloch 1963/64: 234), a not-yet of latent tendencies (Bloch 1959: 356ff). For Bloch nature is a subject (ibid.: $777,785 f$ ), natura naturans, it is creative matter (ibid.: 787) that is oriented on the horizon of the future (Bloch 1962: 410). He speaks of a society where nature and human subject are mediated in a non-alienated form (ibid.: 777,787 ) and where humans recognize that nature co-produces (Mitproduktivität) human livelihood (ibid.: 782).

But there is also a deterministic tendency in Bloch's thinking because he argues that there is a finality and a goal (ultimum) of the world process (Bloch 1959: 232f, 360f). Bloch also seems to have thought that technology doesn't need to be transformed in a free society and that it is as such already socialist in character (Bloch 1959: 769). Hence he believed e.g. that there can be a humanistic use of nuclear power (ibid.: 776). Marcuse other than Bloch didn't see a teleology in nature, he argued that the "idea of the liberation of nature stipulates no such plan or intention in the universe: liberation is the possible plan and intention of human beings, brought to bear upon nature" (Marcuse 1972: 66), nature is a "subject without teleology" (ibid.). Marcuse more realistically than Bloch spoke of the need to transform the productive forces in a free society, of the need of a new technology in a new society. "[...] political change would turn into qualitative social change only to the degree to which it would alter the direction of technical progress that is, develop a new technology" (Marcuse 1964: 227). Rudolf Bahro similarly to Marcuse has argued for the need of alternative technologies, "humanity has not only to transform its relations of production, but must also fundamentally transform the entire character of its mode of production, i.e. the productive forces, the so-called technostructure. [...] We must learn that socialism cannot be the continuation of this industrial system it must involve a break with it. [...] Science and technique can certainly be applied in a different direction, if there is a different society which shapes technology by its own standard, by the standard of the human beings who constitute it" (Bahro 1982: 27, 129f). André Gorz (1977: 134) has argued that a Communist revolution must also be a revolution of technology and consumption structures because the productive forces would be matrices of hierarchic social relationships and monopolies. Murray Bookchin (1971) says that an alternative technology in an alternative society should be organized in the form of decentralized technologies integrated into decentralized, self-managed communities that federate in a participatory commune of the communes. A high degree of automation and eco-technologies would be necessary for social and ecological sustainability. Such a technology could be a post-scarcitytechnology and a technology for life that enables a post-scarcity-society. Advances in technology such as miniaturization could result in a reduction of the workday, providing people with the free time necessary to engage in self-management and democratic municipal assemblies. Bookchin stresses that machinery is neither immanently enslaving nor liberating, but that it has liberating potentials. Automation should be further advanced in a free society and the decentralization of society should be accompanied by a decentralization of technology in order to serve the needs of local communities. He also stresses the idea of multi-purpose-machine and argues that technology has a dialectical character, it makes possible and (today) endangers human existence.

Such ideas reflect the insight that productive technology is a foundation of a free society, but that a qualitatively transformed society must qualitatively transform technology in order to get rid of the latter's destructive potentials, i.e. it must find means of appropriating nature in sustainable ways. Taking a closer look at Bloch's concept of technology shows that on the one hand he underestimated the destructive potentials of technology in Socialism, but on the other hand he argued like Marcuse for a qualitative transformation of technology. E.g. he says that man needs to take on a friendly relationship to nature (Bloch 1959: 783), that man needs to be at home in nature (ibid.: 784), and that he needs to establish an alliance technology. "The more there would instead of the extrinsic technology an alliance technology, one that is mediated with the co-production of nature, the more consequently the creative forces of a frozen 
nature would be again unleashed. Nature is not the past, it is the construction site which is not cleared yet, the not yet adequately existing building materials for the not yet adequately existing human home. [...] Our present technology's place in Nature is like that of an army of occupation in enemy territory. It knows nothing about the interior and the material is over its head" (Bloch 1959: 807, 814). An alliance technology would try to reconcile itself with the hypothetical subject of nature (Bloch 1975: 251). The notion of an alliance technology is an indication that Bloch on the one hand believed in a need for a qualitatively transformed technology, but on the other hand he to a certain extent contradicted this idea.

For Alfred Schmidt (1971: 56) Ernst Bloch's concept of nature as a subject is a non-materialist, pantheistic, hylozoistic notion. That Bloch and Marcuse see nature as a subject doesn't mean that they have an esoteric conception of nature or that they share the views of Deep Ecology on nature (as has e.g. been argued in Light (2004) and Luke (2004)) or that they assume that nature is animistic or has inherent values (as argued in the case of Marcuse by Vogel 2004). Seeing nature as a subject means that matter is self-organizing, it produces itself according to an internal logic and these processes result in the emergence of different organizational levels of matter in such a way that a higher level sublates lower ones. Hence human social matter is based on nature, but also differs from it, the self-organization processes in nature and society have common features, but at the same time there are certain features of society such as self-conscious human beings that can make different practical choices that distinguish the latter from nature. Hence acknowledging that both nature and society are dynamic and dialectical doesn't automatically mean that one naturalizes society and hence becomes trapped in an ideological concept like Stalinism did because one can distinguish general dialectical principles as well as specific ones that apply for concrete natural or social systems. To argue that nature is a subject that produces and organizes itself enables one to argue that there is no need to assume an external creator of nature (God) - hence it has atheistic implications - and that society forms yet another specific level of the dialectical production process of nature that accords both to general and specific (social) dialectical principles and that is hence connected and based on nature. Once one acknowledges that society is both in need of human labour, communication, co-operation and a natural substratum, one sees that nature just like social relationships needs to be sustained in order to reach a society that can provide a good life for all its human members. The material forms that are produced by nature which acts as a material subject and that are transformed and appropriated by man as a societal subject by labour with the help of technology, can only truly become goods that serve the satisfaction of human needs for all if man abolishes the status of nature and humans as objects of destruction and accumulation and transforms himself into a self-determined free societal subject. Nature is not a passive block that can be endlessly destroyed by man, it is active matter that negatively feeds back on society if it is confronted by man in unsustainable ways. Describing nature as a subject implies that if man destroys nature the latter as a producing subject will probably produce uncontrollable negative effects on society and that hence nature should be appropriated in sustainable ways.

One can find certain passages in the writings of Marx that indicate that to a certain extent he just like Marcuse and Bloch considered nature as an active, producing, self-organizing subject. He speaks of the "co-operation of the forces of nature - the increase of human labour-power through the use and exploitation of the forces of nature working" (Marx 1862/63 (1): 19). Here nature is considered as an active, working, co-operating system. The idea of a co-operation of nature and society is also employed in another passage where Marx says that "nature, through whose co-operation a definite quantity of organic matter - plant seeds, a number of animals - enables labour to transform more inorganic matter into organic" (Marx 1862/63 (1): 21). Marx argues that by labour man develops the "slumbering powers" of nature (Marx 1867: 192), that nature is "the primary source of all instruments and subjects of labor" (Marx 1875: 15), and that a "material substratum is always left, which is furnished by Nature without the help of man. The latter can work only as Nature does, that is by changing the form of matter. Nay more, in this work of changing the form he is constantly helped by natural forces" (Marx 1867: 57f). Such descriptions 
of nature as co-operating, working, furnishing, having slumbering powers, and being a producing source run counter to the tendency to argue that Marx saw nature just as a passive object that should be exploited by society, they show that for Marx both nature and the human being are active beings. Consequently Marx anticipated environmental concerns by e.g. speaking of the necessity of "human participation in nature" (Marx 1857/58: 602)

For Steven Vogel (1996) nature is socially constructed, the environment would be a socially built environment, a result of human action. "Nature never appears as it 'is', but rather always as already the nature of a particular social order, in a particular context, subject to a particular set of mediations. [...] The objects 'naturally' surrounding us have social roles and meanings; they are literally 'social constructs,' built by human labour; the 'natural environment' is never encountered independently of its social context" (Vogel 1996: 37f). He argues that Marcuse's account of nature is very similar to the one of "romanticism and Lebensphilosophie" (Vogel 1996: 135), nature here would be "unfolding according to an immanent logic based on a romantic metaphysics in which human action serves only as catalyst" (ibid.: 137). Marcuse's dream of a world where toil is abolished would leave no room for human practice (ibid.: 139) and would hate the world (ibid.). There would be no room for human practice in Marcuse's utopian vision. Vogel argues that Marcuse's idea of a new rationality is "an out-and-out-idealism" (ibid.: 105) because it would be based on the assumption that in a free society nature itself would change.

Vogel overlooks the importance of Marcuse's emphasis that a liberated society must also liberate technology and that technology itself needs to be qualitatively changed in order to become an alternative, sustainable technology. He misunderstands Marcuse's concept of nature and puts forward a reductionist conceptions of nature and society that reduce nature to society. Nature is indeed socially constructed, at least that part of nature that is known to man, but Vogel doesn't want to see that man has produced productive and creative potentials of nature that can be fully developed in order to liberate practice from toil, alienation, and exploitation only in a free society. Vogel ignores that not only nature is social but that also society is natural to the degree that nature forms a productive material potential that should be used by man in order to advance his liberation from hard labour. Marcuse's vision is in fact a very humane one because he believes that human practice can realize its own potentials in relationship to nature with the help of alternative technologies and that freedom is inherently connected to freedom from necessity, toil, and hardship. The argument that "real labour in the world is hard" (Vogel 1996: 139) naturalizes and fetishizes exhausting manual labour as the essence of human practice and lacks an ethical dimension of alleviating labour from hardship by making use of technology. It doesn't see the importance of Marx's notion of well-rounded human practice that realizes creative potentials of all individuals that has been taken up by Marcuse as a concrete ethical vision that could based on a high level of productivity based on an alternative mode of appropriation of nature and on alternative technologies be realized today. Vogel is blind for the humanistic potential of technology and the man-nature-relationship. He misunderstands Marcuse's concept of nature as an irrational teleological resurrection of spiritual forces of nature, but Marcuse believed in the possibility of an alternative society-nature-relationship that sustains human freedom. Marcuse stated that nature is non-teleological and that the opportunity of a free society is based on a potential of nature that has been produced by human practice and can only be realized by the latter. Like Jürgen Habermas (1969) who argued that Marcuse's approach is too utopian and that there is only one anthropological project of technology that man can make use of in order to transform and liberate society, Vogel is blind for the possibility of an alternative, sublated technology based on an alternative, sublated society that allows the eradication of human suffering and hardship. They are both pragmatic and lack materially realistic visions.

Vogel argues that nature and animals would be unable to talk and that hence they would not have the ability to engage in moral argumentation, values could only be determined by human beings. "The question of how we are to approach and interact with nature can be answered only by us, in our own discussions with each other; no solution to it can be read off from nature 'itself' in the manner that 
Marcusean naturalism believed was possible, nor from any sort of transcendental considerations either. [...] Nature, I have argued, is not independent of the subjective, but this does not mean that it is another subject: rather it is something we constitute in our social (and communicatively organized) practices. [...] Questions about nature implicitly refer to a set of communicatively organized processes in which humans transform the world around them and thereby constitute their environment, and that only for that reason are normative questions about that environment both meaningful and (discursively) answerable" (Vogel 1996: 165, 167f). I think that Marcuse would agree to most of these statements because what Vogel misunderstands is that also Marcuse considered nature and values as socially constructed and nonteleological. He would detest Deep Ecology's assumptions about inherent values of nature that frequently result in Ecofascist arguments because his theory was oriented on humane goals and the improvement of the living conditions of human beings. What Vogel leaves out in his account is the fact that human practice has produced certain material potentials in the nature-society-relationship that could be realized by societal transformations and that could create well-being for all. What Marcuse explicitly stresses is that today there is as a result of historical processes a productive potential (which is historical and nonteleological, i.e. a result of human practice) of nature and technology that society should realize and that such a realization would imply a Communist society in the sense of Marx's realm of freedom.

\section{Conclusion}

Nature and society are mutually connected. Man changes and socially constructs nature and parts of nature are incorporated into society as the latter's material foundation. Although there are some elements in the works of Marx and Engels where nature is considered as an endlessly exploitable resource, they can be seen as precursors of ecological thinking and sustainable development. In Orthodox Marxism dialectical thinking has been interpreted as deterministic and mechanic laws and misused for arguing that the Soviet system is a free society. An alternative is a dialectic that stresses human practice and that structures condition alternative possibilities for action. Dialectic thinkers like Herbert Marcuse and Ernst Bloch have argued that nature is a producing subject, a non-teleological subject (Marcuse). Describing nature as a subject implies that if man destroys nature the latter as a producing subject will probably produce uncontrollable negative effects on society and that hence nature should be appropriated in sustainable ways. Matter is a natural subject that acts upon itself, whereas man is a human self-conscious subject that acts upon nature and society.

\section{References}

Altvater, Elmar (1992) Der Preis des Wohlstands oder Umweltplünderung und neue Welt(un)ordnung. Münster. Westfälisches Dampfboot.

Bahro, Rudolf (1982) Socialism and Survival. London. Heretic Books.

Beckenbach, Frank/Diefenbacher, Hans (Eds.) (1994) Zwischen Entropie und Selbstorganisation. Perspektiven einer ökologischen Ökonomie. Marburg. Metropolis.

Bloch, Ernst (1959) Das Prinzip Hoffnung. 3 Volumes. Frankfurt/Main. Suhrkamp.

Bloch, Ernst (1962) Subjekt-Objekt. Erläuterungen zu Hegel. Frankfurt/Main. Suhrkamp.

Bloch, Ernst (1963/64) Tübinger Einleitung in die Philosophie. Frankfurt/Main. Edition Suhrkamp.

Bloch, Ernst (1975) Experimentum Mundi. Frankfurt/Main. Suhrkamp.

Bookchin, Murray (1971) Towards a Liberatory Technology. In: Bookchin, Murray (1971) Post Scarcity Anarchism. San Francisco. Ramparts Press. pp 85-139.

Bookchin, Murray (1988) Yes! - Whither Earth First? In: Green Perspectives, No. 10 (Sep. 1988). http://dwardmac.pitzer.edu/Anarchist Archives/bookchin/gp/perspectives10.html

Bookchin, Murray (1993) What is Social Ecology? In: Zimmerman, M.E. (Ed.) Environmental Philosophy: From Animal Rights to Radical Ecology. Englewood Cliffs. Prentice Hall.

Bookchin, Murray (1994) What is Communalism? http://dwardmac.pitzer.edu/anarchist archives/bookchin/CMMNL2.MCW.html

Bookchin, Murray (1995) The Philosophy of Social Ecology. Essays on Dialectical Naturalism. Montréal/New York/London. Black Rose Books.

Engels, Friedrich (1845) Die Lage der arbeitenden Klasse in England. MEW, Vol. 2. Berlin. Dietz. pp. 225-506. 
Engels, Friedrich (1880) Die Entwicklung des Sozialismus von der Utopie zur Wissenschaft. MEW 19. Berlin. Dierz. pp. 177-228. Engels, Friedrich (1886) Dialektik der Natur. MEW, Vol. 20. Berlin. Dietz. pp. 305-570.

Enzensberger, Hans Magnus (1996) A Critique of Political Ecology. In: Benton, Ted (Ed.) The Greening of Marxism. New York/London. Guilford Press. pp. 17-49.

Foreman, David (1991) Confessions of an Eco-Warrior. New York. Harmony Books.

Foster, John Bellamy (2002) Ecology Against Capitalism. New York. Monthly Review Press.

Fuchs, Christian (2002) Krise und Kritik in der Informationsgesellschaft. Wien/Norderstedt. Libri BOD.

Fuchs, Christian (2003a) Co-operation and Self-Organisation. In: tripleC. Vol. 1 (2003), No. 1, pp. 1-52.

Fuchs, Christian (2003b) Dialectical Philosophy and Self-Organisation. In: Arshinov, Vladimir/Fuchs, Christian (Eds.) (2003) Causality, Emergence, Self-Organisation. Moscow. NIA-Priroda, pp. 195-244.

Fuchs, Christian (2003c) Some Implications of Pierre Bourdieu's Works for a Theory of Social Self-Organization. In: European Journal of Social Theory. Vol. 6, No. 4. pp. 387-408.

Fuchs, Christian (2003d) Structuration Theory and Self-Organization. In: Systemic Practice and Action Research. Vol. 16 (2003), No. 4. pp. 133-167.

Fuchs, Christian (2003e) The Role of the Individual in the Social Information Process. In: Entropy, Vol. 5 (2003), No. 1. pp. 34-60. BBB

Fuchs, Christian (2003f) The Self-Organization of Matter. In: Nature, Society, and Thought. Vol. 16 (2003), No. 3, pp. 281-313.

Fuchs, Christian (2004) The Antagonistic Self-Organization of Modern Society. In: Studies in Political Economy, No. 73 (2004), pp. 183- 209.

Fuchs, Christian/Schlemm, Annette (2005) The Self-Organization of Society. In: Zimmermann, Rainer/Budanov, Vladimir (Eds.) (2005) Towards Otherland. Languages of Science and Languages Beyond. INTAS Volume of Collected Essays 3. Kassel. Kassel University Press. pp. 110-122.

Gare, Arran (1996) Soviet Environmentalism. The Path Not Taken. In: Benton, Ted (Ed.) The Greening of Marxism. New York/London. Guilford Press. pp. 111-128.

Geertz, Clifford (1973) The Interpretation of Cultures. New York. BasicBooks.

Görg, Christoph (2001) Risiko Gesellschaft. Naturverhältnisse in der Theorie Luhmanns. In: Demirovic, Alex (Ed.) (2001) Komplexität und Emanzipation. Kritische Gesellschaftstheorie und die Herausforderung der Systemtheorie Niklas Luhmanns. Münster. Westfälisches Dampfboot. pp. 255-288.

Gorz, André (1977) Ökologie und Politik. Reinbek. Rowohlt.

Gramsci, Antonio (1934) Americanism and Fordism. In: Gramsci, Antonio (1971) Selections from the Prison Notebooks. New York. International Publishers. pp.277-318.

Habermas, Jürgen (1969) Technik und Wissenschaft als "Ideologie". Frankfurt/Main. Suhrkamp.

Harris, Marvin (1989) Kulturanthropologie. New York. Campus.

Harris, Marvin (1997) Culture, People, Nature. An Introduction to General Anthropology. New York. Longman.

Harvey, David (1996) Justice, Nature and the Geography of Difference. Cambridge. Blackwell.

Hegel, Georg Wilhelm Friedrich (1874) The Logic of Hegel. Translated from the Encyclopaedia of the Philosophical Sciences by William Wallace. 2nd Edition. London. Oxford University Press.

Holzkamp, Klaus (1985): Grundlegung der Psychologie. Frankfurt, New York: Campus

Horkheimer, Max/Adorno, Theodor W. (2002) Dialectic of Enlightenment. Stanford. Stanford University Press.

Kropotkin, Peter (1914) Gegenseitige Hilfe in der Tier- und Menschenwelt. Vieanna/Grafenau. Monte Verita/Trotzdem. 1989.

Lenin, Vladimir I. (1918) The Immediate Tasks of the Soviet Government. In: Lenin's Collected Works. Vol. 27. Moscow. Progress. pp. 235-277.

Lévi-Strauss, Claude (1981) Die elementaren Strukturen der Verwandtschaft. Frankfurt/Main. Suhrkamp.

Light, Andrew (2004) Marcuse's Deep-Social Ecology and the Future of Utopian Environmentalism. In: Abromeit, John/Cobb, W. Mark (Eds.) (2004) Herbert Marcuse. A Critical Reader. New York. Routledge. pp. 227-235.

Lipietz, Alain (1996) Political Ecology and the Workers' Movement: Similarities and Differences. In: Callari, Antonio/Ruccio, David F. (1996) Postmodern Materialism and the Future of Marxist Theory. Hannover/London. Wesleyan University Press.

Lipietz, Alain (1999) Working for World Ecological Sustainability. In: The Future of th GlobaL Economy: Towards A Long Boom? Paris. OECD. pp. 139-165.

Lipietz, Alain (2000) Political Ecology and the Future of Marxism. In: Capitalism, Nature, Socialism. Vol. 11, No. 1. pp. 69-85.

Lovelock, James (1979) Gaia. A New Look at Life on Earth. Oxford. Oxford University Press.

Luhmann, Niklas (1997) Die Gesellschaft der Gesellschaft. Frankfurt/Main. Suhrkamp.

Luhmann, Niklas (2004) Ökologische Kommunikation. Kann die moderne Gesellschaft sich auf ökologische Gefährdungen einstellen? Wiesbaden. Verlag für Sozialwissenschaften.

Lukács, Georg (1971) History and Class Consciousness. Cambridge, Massachusetts. MIT Press.

Luke, Tim (2004) Marcuse's Ecological Critique and the American Environmental Movement. In: Abromeit, John/Cobb, W. Mark

(Eds.) (2004) Herbert Marcuse. A Critical Reader. New York. Routledge. pp. 236-239.

Marcuse, Herbert (1958) Soviet Marxism. New York. Columbia University Press.

Marcuse, Herbert (1964) One-Dimensional Man. London. Routledge.

Marcuse, Herbert (1972) Counterrevolution and Revolt. Boston. Beacon. 
Marcuse, Herbert (1999) Reason and Revolution. Hegel and the Rise of Social Theory. New York. Humanity Books.

Marx, Karl (1843) Zur Judenfrage. MEW, Vol. 1. Berlin. Dietz. pp 347-377.

Marx, Karl (1844) Ökonomisch-Philosophische Manuskripte. Dietz. Berlin. MEW, Ergänzungsband 1. pp 465-588.

Marx, Karl (1849) Lohnarbeit und Kapital. MEW, Vol. 6. Berlin. Dietz. pp. 397-423.

Marx, Karl (1857/58) Grundrisse der Kritik der politischen Ökonomie. MEW, Vol. 42. Berlin. Dietz.

Marx, Karl (1859) Zur Kritik der politischen Ökonomie. MEW, Vol. 13. Berlin. Dietz. pp. 3-160.

Marx, Karl (1862/63) Theorien über den Mehrwert. MEW, Vol. 26.1, 26.2, 26.3. Berlin. Dietz

Marx, Karl (1867) Das Kapital. Band 1. MEW, Vol. 23. Berlin. Dietz.

Marx, Karl (1875) Kritik des Gothaer Programms. MEW, Vol. 19. Berlin. Dietz. pp. 13-32.

Marx, Karl (1885) Das Kapital. Band 2. MEW, Vol. 24. Berlin. Dietz.

Marx, Karl (1894) Das Kapital. Band 3. MEW, Vol. 25. Berlin. Dietz.

Marx, Karl/Engels, Friedrich (1846) Die Deutsche Ideologie. Berlin. Dietz. MEW, Vol. 3.

Marx, Karl/Engels, Friedrich (1848) Manifest der kommunistischen Partei. Berlin. Dietz. MEW, Vol. 4, pp. 459-493.

Nicolis, Grégoire/Prigogine, llya (1989) Exploring Complexity. New York. Freeman.

O'Connor, James (1998) Natural Causes. Essays in Ecological Marxism. New York/London. Guilford Press.

Prigogine, llya (1996) The End of Certainties. New York. Free Press.

Schmidt, Alfred (1971) Der Begriff der Natur in der Lehre von Marx. Frankfurt am Main/Köln. Europäische Verlagsanstalt.

Singer, Peter (1993) ) Practical Ethics. Cambridge. Cambridge University Press.

Soper, Kate (1996) Greening Prometheus: Marxism and Ecology. In: Benton, Ted (Ed.) The Greening of Marxism. New York/London. Guilford Press. pp. 81-99.

Stalin, Josef W. (1938) Dialectical and Historical Materialism. In: Problems of Leninism. Peking. Foreign Languages Press. pp. 835873.

Vaillancourt, Jean-Guy (1996) Marxism and Ecology: More Benedictine Than Franciscan. In: Benton, Ted (Ed.) The Greening of Marxism. New York/London. Guilford Press. pp. 50-63.

Vernadsky, Vladimir Ivanovich (1945) The Biosphere and the Noosphere. In: American Scientist, Vol. 33, pp. 1-12.

Vogel, Steven (1996) Against Nature. The Concept of Nature in Critical Theory. Albany, NY. State University of New York.

Vogel, Steven (2004) Marcuse and the "New Science". In: Abromeit, John/Cobb, W. Mark (Eds.) (2004) Herbert Marcuse. A Critical Reader. New York. Routledge. pp. 240-245.

Wallerstein, Immanel (1999) Globalization or the Age of Transition? A Long-Term View of the World-System.

http://fbc. binghamton.edu/iwtrajws.htm

World Commission on Environment and Development (WCED) (1987) Our Common Future. Oxford. Oxford University Press. 